\title{
Clearance of HBeAg and HBsAg of HBV in mice model by a recombinant $H B V$ vaccine combined with GM-CSF and IFN-a as an effective therapeutic vaccine adjuvant
}

\author{
Weidong Zhao ${ }^{1}$, Gan Zhao ${ }^{1}$, Shuren Zhang ${ }^{1}$, Xianzheng Wang ${ }^{1}$, Xueping $\mathbf{Y u}^{2}$ and \\ Bin Wang ${ }^{1}$ \\ ${ }^{1}$ Key Laboratory of Medical Molecular Virology of The Ministry of Health and Ministry of Education, School of Basic Medical \\ Sciences, Fudan University, Shanghai, China \\ ${ }^{2}$ Department of Infectious Diseases, Huashan Hospital, Fudan University, Shanghai, China \\ Correspondence to: Bin Wang, email: bwang3@fudan.edu.cn \\ Keywords: GM-CSF; IFN-a; therapeutic vaccine; HBV; Ly6C hi monocyte \\ Received: April 14, 2017 Accepted: October 30, 2017 Epub: July 13, 2018 Published: September 28, 2018
}

Copyright: Zhao et al. This is an open-access article distributed under the terms of the Creative Commons Attribution License 3.0 (CC BY 3.0), which permits unrestricted use, distribution, and reproduction in any medium, provided the original author and source are credited.

\section{ABSTRACT}

Chronic hepatitis B virus (CHB) infection is a significant public threat. Current interferon-a (IFN-a) based therapies and anti-viral drugs have failed to clear the infection in the majority of CHB patients and animal models. In our previous study, we established a combined protocol that employed a 3-day pretreatment with granulocyte-macrophage colony stimulating factor (GM-CSF) prior to a standard HBV vaccine. It achieved a $90 \%$ reduction of $\mathrm{HBsAg}$ level in the HBsAg transgenic mouse model. This protocol, while effective, remains too complex for clinical use. In this study, we formulated a new regimen by combining GM-CSF, IFN-a and a recombinant HBV vaccine (GM-CSF/IFN-a/VACCINE) into a single preparation and tested its efficacy in a HBV infection model. After four vaccinations, both serum HBeAg and HBsAg were cleared, accompanied by a $95 \%$ reduction of $\mathrm{HBV}^{+}$hepatocytes and the presence of a large number of infiltrating $\mathrm{CD8}^{+} \mathrm{T}$ cells in the liver. Mechanistically these robust responses were initiated by a vaccine-induced conversion of CCR2-

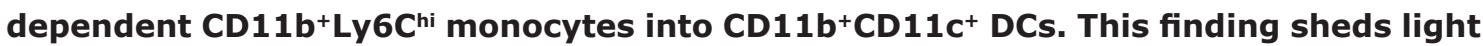
on the potential mechanism of action of the GM-CSF-based vaccine adjuvant and provides definable markers for clinical assessment during future testing of such highly potent vaccine protocols in $\mathrm{HBV}$ patients.

\section{INTRODUCTION}

Hepatitis $\mathrm{B}$ virus (HBV) infection remains as a major global cause of chronic hepatitis B (CHB), liver cirrhosis and hepatocellular carcinoma (HCC) [1]. In $\mathrm{HBV}$-endemic areas, $\mathrm{CHB}$ is a leading risk of HCC [2]. The HBV genome encodes two main antigens, hepatitis $\mathrm{B}$ e antigen ( $\mathrm{HBe} \mathrm{Ag})$ and hepatitis B surface antigen (HBsAg). Pioneer studies have provided overwhelming evidence that the risk of $\mathrm{HCC}$ development in $\mathrm{HBeAg}$ positive patients is significantly higher than in $\mathrm{HBeAg}$ negative ones $[3,4]$. Furthermore, presence of hepatitis B surface antigen (HBsAg) not only leads to immunetolerance $[5,6]$, but also to a higher incidence of hepatocellular carcinoma [7, 8]. Therefore, seroconversion that is detected in $\mathrm{HBeAg}$ and HBsAg tests has become a desired clinical goal and often correlated with preventing HBV-related HCC $[9,10]$.

Immunological tolerance underlies viral persistence during chronic HBV infection $[11,12]$. By the same token, the effectiveness of immunotherapeutic vaccines is linked to vaccine ability to break the tolerance. There are several HBV therapeutic vaccine approaches, based on DNA, peptide and dendritic cells as well as vaccines made of adjuvanted recombinant proteins. They are mainly assessed for potential utility by their associated disturbance of immunotolerance and the degree of $\mathrm{T}$ cell-mediated responses that could lead to clearance of infected cells [13-16]. Yet, none are in routine clinical use due to their various deficiencies. For instance, HBsAg 
protein vaccines gave minimal induction of anti-pre-S2/S antibody in chronic HBV patients [17]. DNA vaccinations that encoded small and middle envelope proteins activated transient and weak T-cell responses and in only a minority of the treated HBV carriers [18]. Yoon and colleagues demonstrated that HB-110, a DNA therapeutic vaccine for HBV treatment, exhibited weaker ability of mediating HBV-specific T cell immunity and HBeAg seroconversion in Korean than in Caucasian patients and animal models [19]. The data from a multicenter clinical trial showed that overstimulation with $\mathrm{HBsAg-HBIG}$ immunogenic complex therapeutic vaccine lead to immune fatigue and actually decreased the host immune response [20]. Another HBV therapeutic vaccine, GS-4774, which was formulated as a heat-inactivated yeast-based vaccine, was designed to evoke immune response against HBV in CHB patients. However, GS-4774 recently failed to meet its primary endpoint in a randomized phase II study [21]. Therefore, the search for an ideal HBV vaccine candidate is an ongoing effort and using cytokines to adjuvant vaccines is an option.

GM-CSF plays an essential role in the proliferation, differentiation, and survival of myeloid lineage cells [22]. Due to its pleiotropic effects on different cell lineages, GMCSF has been used as an adjuvant to elicit immune responses for vaccine development against several infectious diseases and tumors $[23,24]$. Essentially all of the attempts have had limited success. One potential reason for the failure is that, under some circumstances, the use of GM-CSF as a vaccine adjuvant can induce suppressive immune responses [25, 26 ], e.g. by induction of immature DC [27]. Interestingly, we found that such a negative regulation could be tweaked to become immune-activating simply by altering the timing of delivery. The undesirable negative impact of GM-CSF as an adjuvant was solved by using our recently published protocol in which 3-day pretreatments with GM-CSF were given before a vaccination into the same site of animals to elicit potent immune responses. This protocol overcame the immune tolerance and over $90 \%$ reduction of $\mathrm{HBsAg}$ level was observed in the HBsAg transgenic mouse model [28]. While the outcome remains exciting, the protocol by its original design was too complex for potential use in humans as a therapeutic vaccine.

IFN- $\alpha$, the first substance licensed for CHB therapy, can accelerate DC maturation and promote costimulation factor expression and pro-inflammatory cytokine secretion in the presence of GM-CSF [29-31]. In particular, evidence is accumulating that GM-CSF and IFN- $\alpha$ can act together as an effective vaccine adjuvant for antitumor and antiviral immunity in both mouse models and human diseases [32, 33]. A prospective randomized trial in $\mathrm{CHB}$ treatment showed that the combination of GM-CSF and IFN- $\alpha$ was effective in nonresponders to IFN- $\alpha$ monotherapy [34]. However, the use of GM-CSF plus IFN- $\alpha$ as a therapeutic HBV vaccine adjuvant is still not well defined.
In this context, the optimal cocktail therapy that consisted of IFN- $\alpha$, GM-CSF, and recombinant HBV vaccine (VACCINE) was tested in a mouse model using recombinant adeno-associated virus 8 (AAV8)1.3HBV infection. The aim of this study was to assess the immunological efficiency of the combined therapy and explore the role that the GM-CSF plus IFN- $\alpha$ adjuvant played in this therapeutic HBV vaccine protocol.

\section{RESULTS}

\section{GM-CSF plus IFN- $\alpha$ combined with HBV vaccine induces robust immune responses}

DTH is a well-established assay for antigen specific cellular responses to vaccination. To identify the most robust combination formula to induce cell-mediated responses, the HBV vaccine was tested with GM-CSF plus IFN- $\alpha$ as adjuvant at various dose formulations in wild-type C57BL/6 male mice. By using $\mathrm{HBsAg}$ as a re-challenging antigen on day 7 after the second immunization, we found that $10 \mu \mathrm{g}$ of GM-CSF and $10,000 \mathrm{IU}$ of IFN- $\alpha$ combined with $1 \mu \mathrm{g} \mathrm{HBV}$ vaccine (GM-CSF/IFN- $\alpha$ /VACCINE hereafter) could augment DTH responses to HBsAg more strongly than other formulations (Supplementary Figure 1A). Similarly, the anti-HBsAg antibody level was consistently and significantly increased the most with this formulation as compared with other combinations (Supplementary Figure 1B). In fact, excess of GM-CSF was associated with reduced responses. This optimal combination was therefore selected as the base preparation for further analyses.

\section{GM-CSF/IFN- $\alpha$ /VACCINE induces HBsAg sero- clearance and enhances humoral response in an infected mouse model}

A mouse model for persistent $\mathrm{HBV}$ infection was established by employing the AAV8-1.3HBV virus in which 1.3 copies of HBV genome are packaged in a livertropic type 8 AAV vector [35]. The AAV8-1.3HBV virus was found to continually release complete $\mathrm{HBV}$ virions and express $\mathrm{HBeAg}$, $\mathrm{HBsAg}$, and $\mathrm{HBcAg}$ for more than six months. Since HBV-induced immunotolerance was also found in this mouse model, the AAV8-1.3HBV mouse has been accepted as an animal model for chronic hepatitis B immunotherapy studies [35-37], where the general indicators of immunotolerance breaking in $\mathrm{HBV}$ studies are the loss of expression of $\mathrm{HBeAg}$ and $\mathrm{HBsAg}$ in parallel with the respective antiserum conversions.

First, to evaluate whether the GM-CSF/IFN- $\alpha$ / VACCINE has the ability to reduce serum levels of both $\mathrm{HBeAg}$ and HBsAg, the immunotolerogenic animal model with AAV8-1.3HBV infection was established and then immunized with a mixed GM-CSF/IFN- $\alpha$ / 
VACCINE regimens intramuscularly for 3 times at biweekly intervals, and a boost injection three weeks after the third immunization (Figure 1A). Controls were treated with PBS, GM-CSF, IFN- $\alpha$, or VACCINE alone or with GM-CSF/IFN- $\alpha$, GM-CSF/VACCINE or IFN- $\alpha$ / VACCINE combinations. The sera of immunized AAV81.3HBV mice were collected for $\mathrm{HBeAg}$, HBsAg, HBV DNA, anti-HBeAg antibody and anti-HBsAg antibody tests. The liver tissues were collected for HBV DNA, immunological histological chemistry (IHC) and pathology tests. The GM-CSF/IFN- $\alpha$ /VACCINE regimen induced anti-HBeAg antibody (Supplementary Figure 2A) and cleared the e antigens in serum (Figure 1B). Also, this regimen induced HBsAg-specific antibody (Figure 1D) and cleared HBsAg antigens in serum (Figure 1C). These are in drastic contrast to the other treatments, including treatment with vaccine alone. The clearance of $\mathrm{HBeAg}$ and HBsAg were sustainable for at least 24 weeks after the last immunization without rebounds in the GM-CSF/ IFN- $\alpha$ /VACCINE group, whereas no significant changes were observed in the levels of $\mathrm{HBeAg}$ and $\mathrm{HBsAg}$ in the controls. Only the mixed GM-CSF/IFN-/VACCINE group induced a significant $\mathrm{HBsAb}$ response (Figure 1E). Most importantly, the serum HBV DNA was also almost undetectable at the end of the study (Figure 1B).

Since removal of viral DNA, particularly cccDNA of $\mathrm{HBV}$, has been considered a cure, we assessed if our strategy could eliminate the DNA from the liver. Although the animal model does not generate cccDNA as it does in human, HBV genomic DNA can be retained in hepatocytes [37]. We first examined if $\mathrm{HBcAg}^{+}$hepatocytes were cleared by the GM-CSF/IFN- $\alpha$ /VACCINE immunizations and observed that a significant amount of the $\mathrm{HBcAg}^{+}$ hepatocytes were eliminated (Figure 2A). Furthermore,
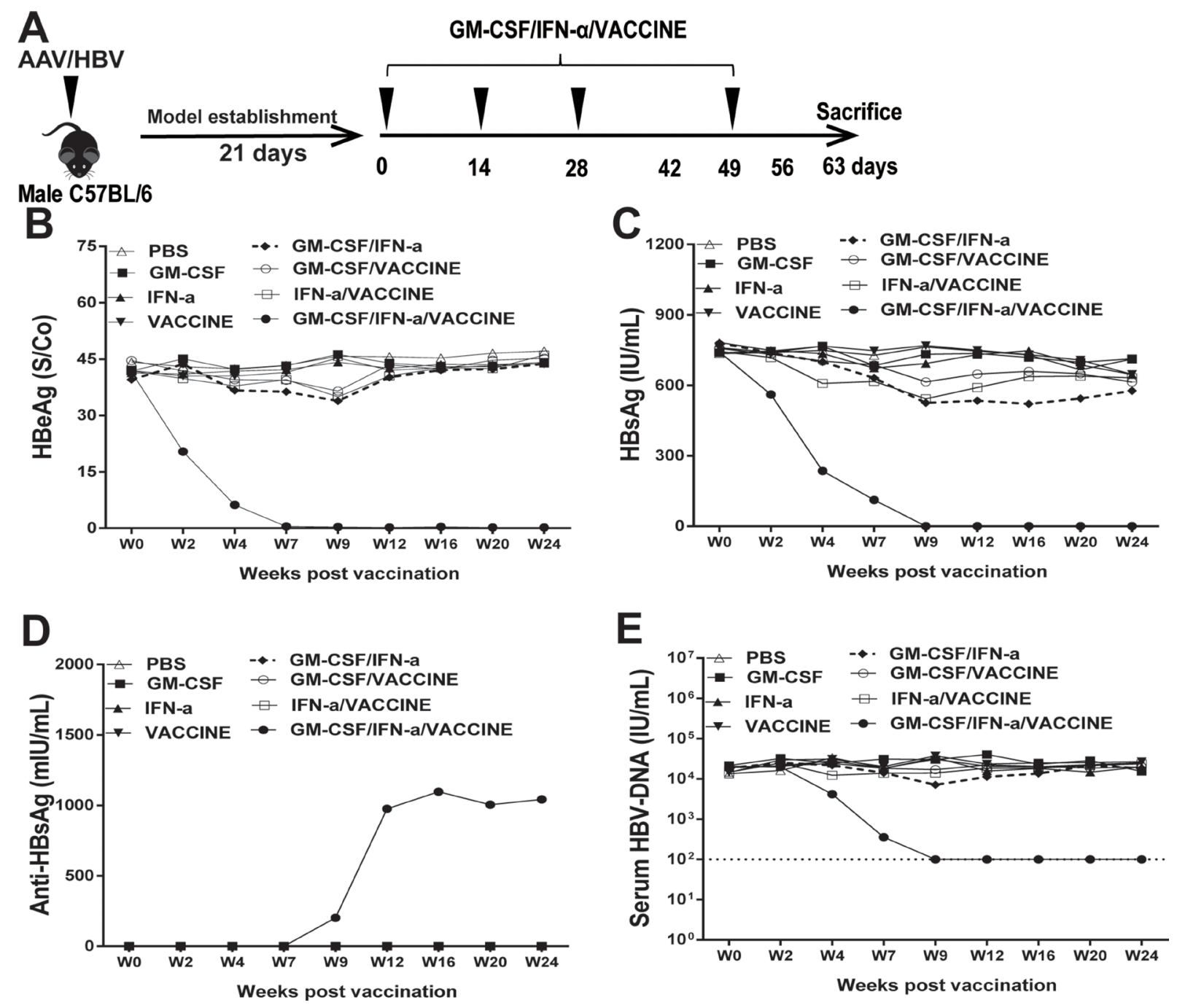

Figure 1: Treatment of AAV8-1.3HBV-infected mice with GM-CSF plus IFN- $\alpha$ combined with VACCINE (GM-CSF/ IFN-a/VACCINE) decreased the infection. (A) Schematic illustration of immunization workflow. Mice were immunized on day 21, 35, 49, and 70 post-infection. (B-E) At intervals up to 24 weeks, blood samples were collected at the indicated time points (week 0, 2 , $4,7,9,12,16,20$, and 24) and the sera tested for HBV DNA, HBeAg and HBsAg, and HBsAb. The dotted line in E represents the assay limit of detection. 
the liver HBV DNA levels had declined $>2 \log _{10} \mathrm{IU} / \mathrm{g}$ in the GM-CSF/IFN- $\alpha$ /VACCINE group, as compared to the controls (Figure 2B). In addition, there was strong association with lymphocyte infiltration found in the GM-CSF/IFN- $\alpha$ /VACCINE-treated mouse livers (Figure 2C). Next we sought to assess any cytolytic effect on the liver after these treatments. Levels of serum ALT were monitored on weeks $0,2,4,7,9,12$ and 16 after commencing the immunizations. In the GM-CSF/IFN- $\alpha$ / VACCINE group a transiently elevating serum level of ALT was observed, which fell back to the normal level five weeks after the last vaccination. Similar but less extended transient elevation of ALT was also found in the other groups, excepting the PBS control (Figure 2D and Supplementary Figure 2). Interestingly, the elevated levels of ALT in the GM-CSF/IFN- $\alpha$ group approached that seen in GM-CSF/IFN- $\alpha$ /VACCINE group. Yet, only the GM-CSF/IFN- $\alpha$ /VACCINE group cleared HBsAg and $\mathrm{HBeAg}$; the GM-CSF/IFN- $\alpha$ group did not (Figure $1 \mathrm{~F}$ and
$1 G)$. It seems that the GM-CSF/IFN- $\alpha$ regimen perhaps induced only non-specific immune responses whereas the GM-CSF/IFN- $\alpha$ /VACCINE regimen additionally elicited the HBV-specific immune responses. Collectively, these results demonstrated that the GM-CSF/IFN- $\alpha$ /VACCINE can break established immune-tolerance in the $\mathrm{HBV}$ infection model, thereby eliciting a spectrum of robust anti-HBV responses that can result in a significant clearance of the viral infection.

\section{Induction of robust cell-mediated response in vivo}

To clear infected hepatocytes, robust antigen specific cellular response is essential. DTH responses in AAV8-1.3HBV-infected mice immunized with different formulations were compared. After using HBsAg at 10 $\mu \mathrm{g} /$ foot-pad as a re-challenging antigen at 14 days after the fourth immunization, the result was that the animals
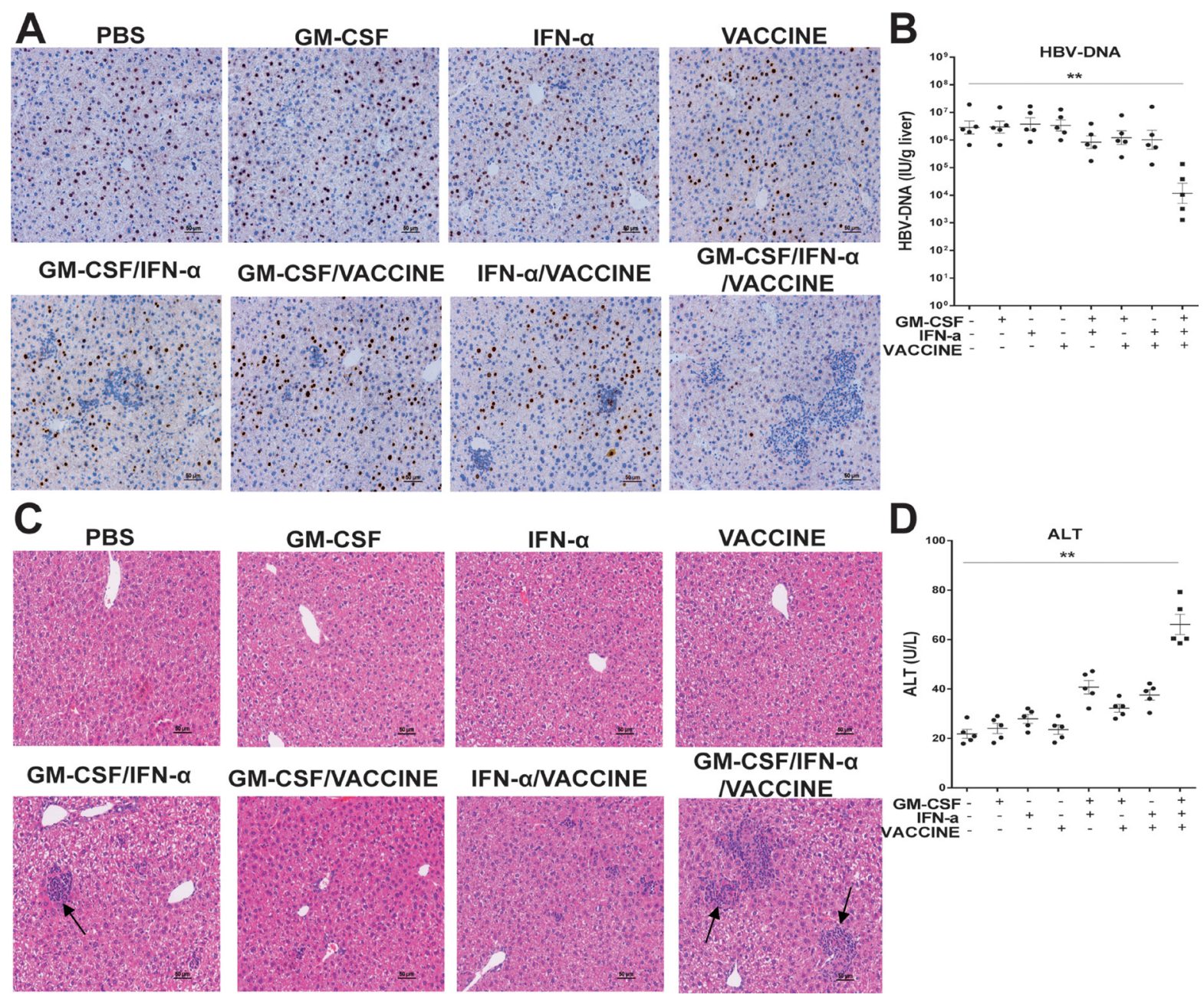

Figure 2: The GM-CSF/IFN-a/VACCINE promoted the clearance of HBcAg-positive hepatocytes. (A) 14 days after the fourth immunization, liver sections were stained for HBcAg (brown staining) by IHC. Scale bar represents $50 \mu \mathrm{m}$. (B) 14 days after the fourth immunization, the HBV DNA levels in liver were analyzed by q-PCR. (C-D) 14 days after the fourth immunization, serum ALT was measured and the liver-infiltrating lymphocytes were stained by H\&E. Scale bar represents $50 \mu \mathrm{m}$. Symbols represent mean $\pm \mathrm{SEM}$. ${ }^{*} P<0.05 ;{ }^{* *} P<0.01$. 
in the GM-CSF/IFN- $\alpha$ /VACCINE treated group produced the highest level $(P<0.01)$ of footpad swelling $24 \mathrm{~h}$ after the sensitization (Figure 3A). To examine the proliferative ability of HBsAg-specific $\mathrm{CD}^{+} \mathrm{T}$ cells after vaccination, splenic cells labeled with CFSE were incubated in vitro with HBsAg-specific CTL epitope $\mathrm{S}_{208-215}$ (ILSPFLPL; $\mathrm{H}$-2b-restricted, $1 \mu \mathrm{g} / \mathrm{L}$ ) as a specific stimulator for $72 \mathrm{~h}$ in the presence of anti-CD28 $(100 \mathrm{ng} / \mathrm{mL})$. As shown in Figure $3 \mathrm{~B}$, the proliferative responses of $\mathrm{HBsAg}$-specific $\mathrm{CD}^{+} \mathrm{T}$ cells were significantly enhanced in the GM-CSF/ IFN- $\alpha$ /VACCINE-treated group compared with the other groups.

To gain mechanistic insight into this potent formulation, we analyzed several parameters of cellular immune responses. When splenocytes from the persistently infected mice that had been treated with GM-CSF/IFN- $\alpha$ / VACCINE were re-stimulated in vitro with $10 \mu \mathrm{g} / \mathrm{mL}$
HBsAg, a markedly higher frequencies of IFN- $\gamma$ and IL-4 secreting $\mathrm{CD}^{+} \mathrm{T}$ cells were found, much greater than in other groups (Figure 3C and Supplementary Figure 3A). Classical cytotoxic $\mathrm{T}$ cells are key to clearing virally infected cells. The GM-CSF/IFN- $\alpha$ /VACCINE regimen induced significantly more $\mathrm{HBsAg}$-specific IFN- $\gamma^{+} \mathrm{CD}^{+} \mathrm{T}$ cells compared to the other immunized groups, not only in the periphery (Figure 3D and Supplementary Figure 3B), but also in the liver, where a large number of $\mathrm{CD}^{+} \mathrm{T}$ cell infiltrates was seen by IHC (Figure 3E). To directly assess in vivo the killing function of the activated $\mathrm{CD} 8^{+} \mathrm{T}$ cells elicited by the GM-CSF/IFN- $\alpha$ /VACCINE, splenocytes from naïve donor $\mathrm{C} 57 \mathrm{BL} / 6$ mice were divided into two parts. One was labeled with $15 \mu \mathrm{M}$ of CFSE and pulsed with $1 \mu \mathrm{g} / \mathrm{mL}$ of HBsAg-derived CTL peptide $\mathrm{S}_{208-215}$ (defined as CFSE ${ }^{\text {high }}$ target cells). The other one was labeled with $1 \mu \mathrm{M}$ of CFSE and pulsed with $1 \mu \mathrm{g} / \mathrm{mL}$ of

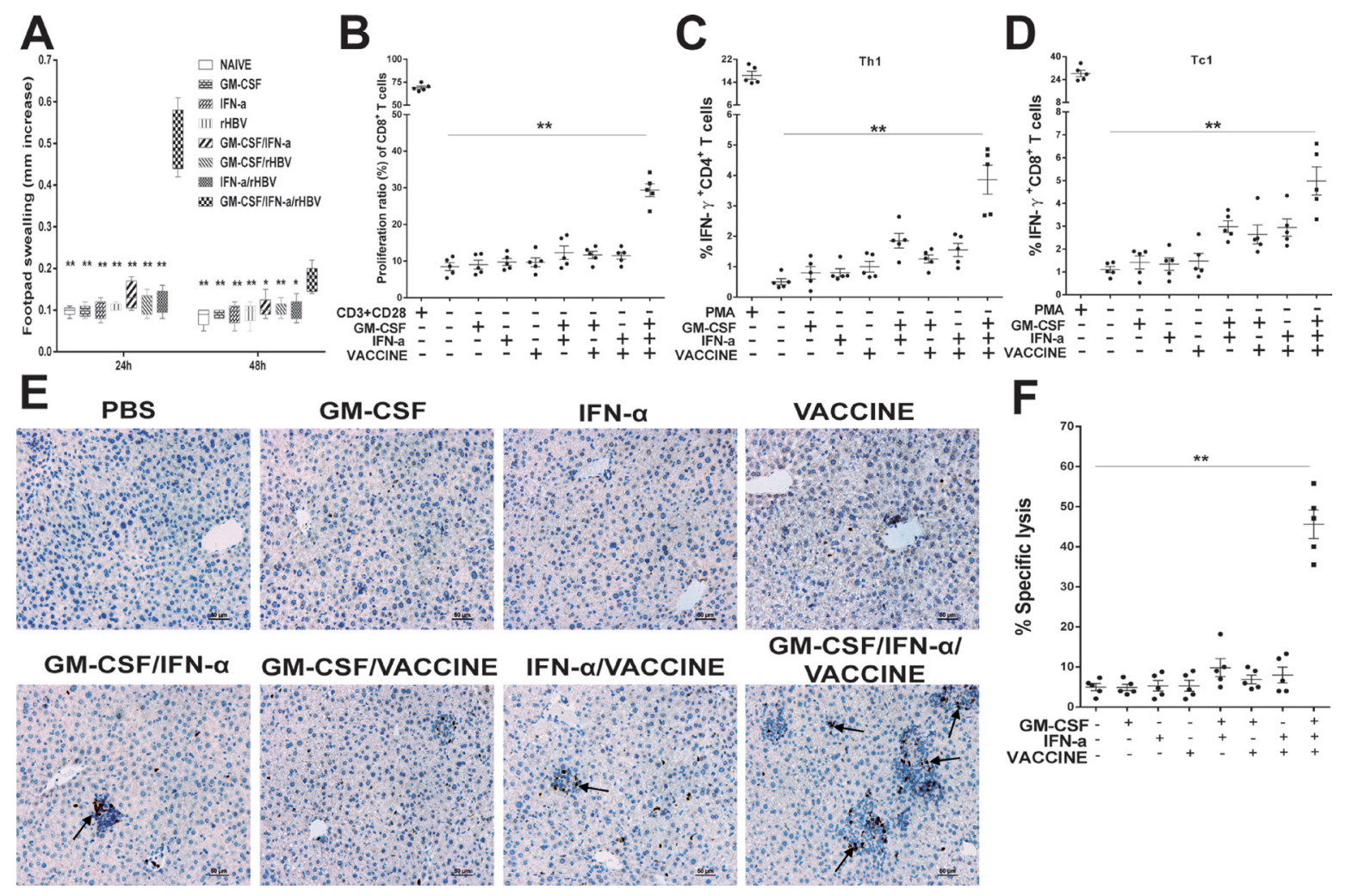

Figure 3: The GM-CSF/IFN- $\alpha$ /VACCINE elicited cellular immunity against AAV8-1.3HBV infection. (A) 14 days after the fourth immunization of the infected mice, a total of $10 \mu \mathrm{g}$ HBsAg was injected into the left footpad and PBS was injected into the right footpad as a control. Changes in footpad thickness were measured 24 and $48 \mathrm{~h}$ after injection to analyze DTH reaction. (B) 14 days after the fourth immunization, CFSE was added at a concentration of $1 \mu \mathrm{M}$ to washed splenocytes $\left(5 \times 10^{5}\right.$ cells $)$. The cells were incubated for $10 \mathrm{~min}$ at $37^{\circ} \mathrm{C}$ in the dark, and labeling was stopped by adding RPMI 1640 supplemented with $10 \%$ fetal bovine serum (FBS). The cells were washed 3 times with medium and transferred to 96-well plates. Then the cells were incubated with HBsAg-specific CTL epitope $\mathrm{S}_{208-}$ ${ }_{215}$ (ILSPFLPL; H-2 ${ }^{\mathrm{b}}$-restricted) as a specific stimulator in the presence of anti-CD28 (100 ng/mL). Cells incubated with anti-CD3 (1 $\mu \mathrm{g} /$ $\mathrm{mL})$ and anti-CD28 $(100 \mathrm{ng} / \mathrm{mL})$ were used as positive controls. The plates were incubated at $37^{\circ} \mathrm{C}$ in a humidified atmosphere with $5 \%$ $\mathrm{CO}_{2}$ for $72 \mathrm{~h}$ before the labeled cells were determined by flow cytometric analysis. The proliferation ratio of CD $8^{+} \mathrm{T}$ cells is presented. C., D. 14 days after the fourth immunization, the splenocytes were stimulated with $\mathrm{rHBsAg}(10 \mu \mathrm{g} / \mathrm{mL})$ for $18 \mathrm{~h}$. All samples included addition of $10 \mu \mathrm{g} / \mathrm{ml} \mathrm{BFA}$ for the last $6 \mathrm{~h}$ of incubation. PMA/ionomycin $(100 \mathrm{ng} / \mathrm{mL} / 1 \mu \mathrm{g} / \mathrm{mL})$ was used as a positive control. Th1 (C) and Th2 (D) cells were then detected by intracellular cytokine. (E) IHC for CD8 ${ }^{+} \mathrm{T}$ cells (brown staining) on liver sections at 14 days after the fourth immunization. Scale bar represents $50 \mu \mathrm{m}$. (F) Characterization of HBsAg-specific CTL activity in vivo in AAV8-1.3HBV infected mice. Percentage of HBsAg-specific CTL activity in vivo is summarized. Bars are shown as mean $\pm \mathrm{SEM}$. ${ }^{*} P<0.05 ;{ }^{* *} P<0.01$. 
OVA-derived CTL peptide OVA ${ }_{257-264}$ (defined as CFSE ${ }^{\text {low }}$ target cells and providing a non-HBV target control). A mixture of $\mathrm{CFSE}^{\text {high }}$ and $\mathrm{CFSE}^{\text {low }}$ cells at a 1:1 ratio was adoptively transferred intravenously into immunized recipients at $2 \times 10^{7}$ cells per mouse on the $14^{\text {th }}$ day after the fourth vaccination. Eight hours later, splenocytes were isolated from the recipients and CFSE fluorescence intensities were analyzed. HBsAg-specific killing was almost $45 \%$ in the GM-CSF/IFN- $\alpha$ /VACCINE group and was $<10 \%$ in other groups (Figure $3 \mathrm{~F}$ and Supplementary Figure $3 \mathrm{C}$ ). Taken together, these data indicate that the GM-CSF/IFN- $\alpha$ /VACCINE regimen can evoke robust HBsAg-specific cell-mediated immune responses in the immune-tolerogenic model created by AAV8-1.3HBV infection. As no specific $\mathrm{TH}$ polarization was found, this new regimen appears to enhance the overall cellular immunity, rather than targeting a specific sub arm of the adaptive immunity.

\section{Activation of CD11 $b^{+}$CD11 $c^{+}$DC}

Effective activation of antigen presenting cells (APC) is the key to mounting effective innate and adaptive immune responses against invading pathogens [38]. By design, the primary function of adjuvants is to activate these cells, particularly DCs. After responding to the GM-CSF/IFN- $\alpha$ /VACCINE in the AAV8-1.3HBV model for $24 \mathrm{~h}, \mathrm{APC}$ in PBMC and local lymph nodes were consecutively collected and examined. The

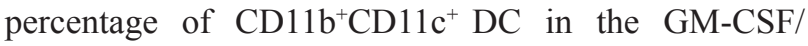
IFN- $\alpha$ /VACCINE group was on average 5-fold higher in the blood (Figure 4A and Supplementary Figure 4A) and 3-fold higher in local lymph nodes (Figure 4B) compared to the control groups. In contrast, plasmacytoid DC (CD11b- PDCA-1 ${ }^{+}$, Supplementary Figure 4B) and

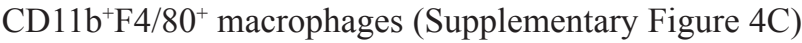
were not significantly altered. To determine the properties of this newly activated $\mathrm{CD} 11 \mathrm{~b}^{+} \mathrm{CD} 11 \mathrm{c}^{+} \mathrm{DC}$ population, we examined changes in the expression of functional markers, CD80, MHC-I and MHC-II. In the GM-CSF/ IFN- $\alpha$ /VACCINE group, the expression of CD80 (Figure 4C), MHC-I (Figure 4D) and MHC-II (Supplementary Figure 4D) were significantly increased as compared with the control groups. Since cytokines play vital roles in modulating immune responses, we evaluated whether the GM-CSF/IFN- $\alpha$ /VACCINE could synergistically affect cytokine production. Some key inflammatory cytokines and chemokines in serum were determined by ELISA. Increased production of serum IL-12 (Figure 4E) and IL-4 (Supplementary Figure 4E) was observed $(P<0.01)$. A similar trend $(P<0.01)$ was found for monocyte chemoattractant protein-1 (MCP-1), a chemokine that attracts monocytes infiltrating into the inflammation site (Figure 4F). Hence, the results revealed that the GM-CSF/IFN- $\alpha$ /
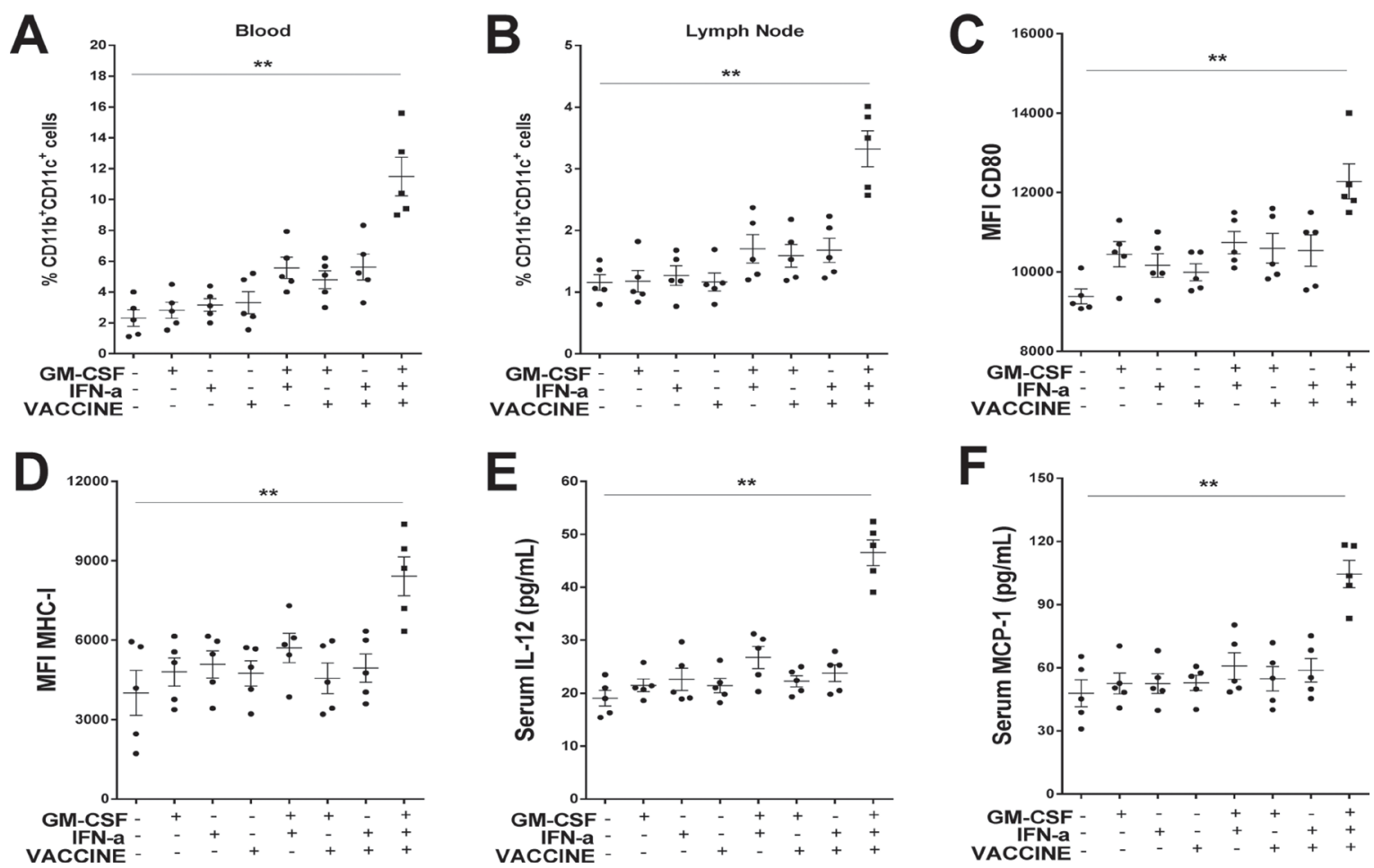

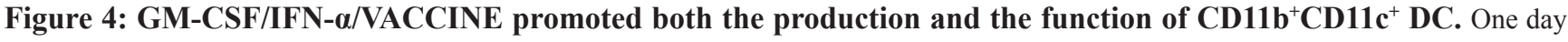
after the second immunization, blood and inguinal lymph node samples were collected and analyzed. (A-B) Percentage of CD11 $\mathrm{b}^{+} \mathrm{CD} 11 \mathrm{c}^{+}$ DC in blood and in inguinal lymph nodes of AAV8-1.3HBV-infected mice inoculated with different formulations of the vaccine. $(\mathbf{C}-$ D) Comparison of markers on of CD11b ${ }^{+} \mathrm{CD} 11 \mathrm{c}^{+}$DC in blood: CD80 and MHC-I. (E-F) Serum concentration of IL-12 and monocyte chemoattractant protein-1 (MCP-1). Bars represent mean \pm SEM. ${ }^{* *} P<0.01$. 
VACCINE-mediated immune enhancements can be at least partially explained by a heightened $\mathrm{CD} 11 \mathrm{~b}^{+} \mathrm{CD} 11 \mathrm{c}^{+}$ $\mathrm{DC}$ activation in vivo.

\section{GM-CSF/IFN- $\alpha$ /VACCINE drives the production of $\mathrm{CD} 11 \mathrm{~b}^{+} \mathrm{Ly}^{6} \mathrm{C}^{\text {hi }}$ monocytes}

Monocyte-derived DCs (MoDC) have been shown to be continuously generated from blood Ly $6 \mathrm{C}^{\text {hi }}$ monocytes $[39,40]$. To examine the effects of GM-CSF plus IFN- $\alpha$ on monocyte differentiation into MoDC,

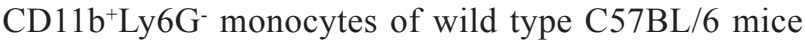
were sorted from the peripheral blood (Supplementary Figure 5A) and treated with GM-CSF plus IFN- $\alpha$ for 3 days in vitro. Cells treated with LPS, GM-CSF or IFN- $\alpha$ alone or untreated were used as controls. Indeed GMCSF plus IFN- $\alpha$ promoted a higher rate of conversion to $\mathrm{CD} 11 \mathrm{c}^{+} \mathrm{DC}$ than either GM-CSF or IFN- $\alpha$ used alone (Figure 5A and 5B). This was accompanied by a higher level of the co-stimulatory molecule CD80 (Figure 5C), CD86 (Figure 5D), MHC-I (Figure 5E) and MHC-II (Figure 5F), indicating a change similar to the in vivo observation. In a functional assay, GM$\mathrm{CSF} / \mathrm{IFN}-\alpha$-derived MoDC were primed with $10 \mu \mathrm{g} / \mathrm{mL}$ HBsAg for $24 \mathrm{~h}$ and then mixed with purified splenic $\mathrm{CD}^{+} \mathrm{T}$ cells $\left(2 \times 10^{5}\right.$ cells/well $)$ from AAV8-1.3HBV infected mice at a T:MoDC ratio of 10:1. A significantly higher level of $\mathrm{CD}^{+} \mathrm{T}$ cell proliferation was induced by incubation with the GM-CSF/IFN- $\alpha$ derived MoDC than was induced by other protocols (Figure $5 \mathrm{G}$ and Supplementary Figure 5B).

Having demonstrated that GM-CSF/IFN- $\alpha$ could effectively cause differentiation of monocytes into MoDC in vitro, it was important to study which subtypes of monocytes contributed to this process in the HBV immune-tolerant animals. We first infected mice with AAV8-1.3HBV and subsequently immunized with the GM-CSF/IFN- $\alpha$ /VACCINE twice with a 2-week interval, and then collected monocytes from PBMC $24 \mathrm{~h}$ later. An average 2.5-fold increase in the $\mathrm{CD} 11 \mathrm{~b}^{+}$Ly6 $\mathrm{C}^{\text {hi }}$ monocytes was found in the blood $24 \mathrm{~h}$ later (Figure $5 \mathrm{H}$ and 5I). However, this treatment did

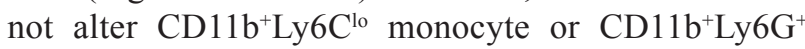
granulocyte numbers (Supplementary Figures $5 \mathrm{C}$ and 5D). CCR 2 on Ly6C $\mathrm{C}^{\text {hi }}$ monocytes plays an essential role in mediating their trafficking to inflammatory sites [41, 42] and an elevation of MCP-1 (a CCR2 chemotactic ligand) was found in the blood of GM-CSF/IFN- $\alpha$ / VACCINE-treated group (Figure 4F). Echoing this finding, CCR2 was significantly up-regulated among the $\mathrm{CD} 11 \mathrm{~b}^{+} \mathrm{Ly} 6 \mathrm{C}^{\text {hi }}$ monocytes in the PBMC of the GM-CSF/ IFN- $\alpha$ /VACCINE group, as compared with other groups (Figure 5J and Supplementary Figure 5E), suggesting that this receptor ligand interaction may be important for the migration of $\mathrm{CD} 11 \mathrm{~b}^{+} \mathrm{Ly} 6 \mathrm{C}^{\text {hi }}$ monocytes to the infected sites of immunized animals.

\section{Blockage of Ly6C ${ }^{\text {hi }}$ monocytes abrogates HBV clearance in AAV8-1.3HBV model}

We next determined if the conversion of Ly6 $\mathrm{C}^{\mathrm{hi}}$ monocytes to MoDC was essential to the robust adaptive immune responses and anti-viral effects associated with the combination regimen. INCB3344, a selective CCR2 antagonist [43-45] was injected i.p. at $30 \mathrm{mg} / \mathrm{kg}$ per day into AAV8-1.3HBV infected mice $1 \mathrm{~h}$ before the GM-CSF/ IFN- $\alpha$ /VACCINE inoculation, and again on days 2 and 3. PBS and 10\% DMSO were used as controls. PBMC were collected and analyzed $12 \mathrm{~h}$ after the third administration of INCB 3344. The selective blockade of CCR2 significantly decreased the generation of CD $11 \mathrm{~b}^{+} \mathrm{Ly} 6 \mathrm{C}^{\mathrm{hi}}$ monocytes (Figure 6A and 6B) and $\mathrm{CD} 11 \mathrm{~b}^{+} \mathrm{CD} 11 \mathrm{c}^{+} \mathrm{DC}$ (Figure 6C), without affecting $\mathrm{CD} 11 \mathrm{~b}^{+} \mathrm{Ly} 6 \mathrm{C}^{\mathrm{lo}}$ monocytes, $\mathrm{CD} 11 \mathrm{~b}^{+} \mathrm{Ly}_{6 \mathrm{G}^{+}}$granulocytes, $\mathrm{T}$ cells or NK cells (data not shown). This demonstrated that the GM-CSF/IFN- $\alpha /$ VACCINE-induced CD $11 \mathrm{~b}^{+} \mathrm{CD} 11 \mathrm{c}^{+} \mathrm{DC}$ were derived from CD $11 b^{+}$Ly6 $\mathrm{C}^{\text {hi }}$ monocytes in a CCR2-dependent manner.

To further define the importance of CCR2 expression on Ly6 $\mathrm{C}^{\mathrm{hi}}$ monocytes, we examined if CCR2 blockade could result in abrogation of the clearance of HBsAg. Fourteen days after the fourth immunization, serum samples were collected for ALT, HBsAg and HBV DNA detection by ELISA and splenocytes were harvested and re-stimulated with $\mathrm{HBsAg}(10 \mu \mathrm{g} / \mathrm{mL})$ for $18 \mathrm{~h}$ in vitro to test their capacity for IFN- $\gamma$ production. As depicted in Figures 6D and 6E, the use of INCB 3344 led to significant reduction of HBsAg specific IFN- $\gamma$-secreting $\mathrm{CD} 8^{+} \mathrm{T}$ cells as well as reduction of ALT level after the GM-CSF/IFN- $\alpha$ /VACCINE immunizations. Conversely, the beneficial effects of the combination vaccine was essentially lost in terms of the serum levels of HBsAg and HBV DNA or HBcAg-positive hepatic cells in infected mice (Figures 6F, 6G, and 6H). This result demonstrated that induction of $\mathrm{Ly}_{6 \mathrm{C}}{ }^{\mathrm{hi}} \mathrm{CCR} 2^{+}$monocytes by the immunizations with GM-CSF/IFN- $\alpha$ /VACCINE was crucial to mounting effective adaptive anti-viral responses, particularly to markedly elevating the levels of antigenspecific IFN- $\gamma$-secreting $\mathrm{CD} 8^{+} \mathrm{T}$ effector cells.

\section{DISCUSSION}

In this study, we observed that a regimen consisting of GM-CSF, IFN- $\alpha$, and recombinant human HBV vaccine (VACCINE) administered into animals induced a robust antigen-specific immune response. This was characterized by $100 \%$ seroconversion of $\mathrm{HBeAg}$ and $\mathrm{HBsAg}$ along with a significant reduction of viral DNA in sera and elimination of $\mathrm{HBcAg}$-positive hepatocytes in the AAV81.3HBV-infected mouse model. Further study revealed that the significant therapeutic effects were initiated by activation of $\mathrm{Ly} 6 \mathrm{C}^{\mathrm{hi} \mathrm{CCR} 2+}$ monocytes that are essential in recruitment and induction of $\mathrm{CD} 11 \mathrm{~b}^{+} \mathrm{CD} 11 \mathrm{c}^{+} \mathrm{DC}$. The therapeutic effect of the GM-CSF/IFN- $\alpha / \mathrm{VACCINE}$ 
administrations arose by breaking the HBV-induced immunotolerance. This resulted in the recruitment and conversion of monocytes into moDC and these generated the robust responses: HBsAg-specific $\mathrm{T}$ cell proliferation, cytolytic $\mathrm{CD}^{+} \mathrm{T}$ cell activity and $\mathrm{B}$ cell production of anti-HBsAg antibodies. This novel regimen thus provides a simple yet highly effective therapeutic treatment for CHB that has long been desired by the field.

GM-CSF was the first cytokine documented to promote differentiation of myeloid lineage cells into DC [46]. Due to its effects, GM-CSF has been exploited as an adjuvant for virus and cancer vaccines in different animal models [47, 48]. However, results in human trials were largely disappointing and sometimes associated with opposite effects $[49,50]$. In contrast, some investigations had demonstrated that GM-CSF combined with other cytokines as a combined adjuvant was more effective than GM-CSF alone [51, 52]. This is again proven true in this and our previous work [28].

Monocytes are cells with high differentiation potential and can differentiate into M1 macrophages in the presence of GM-CSF and IFN- $\gamma$, or into DC on exposure
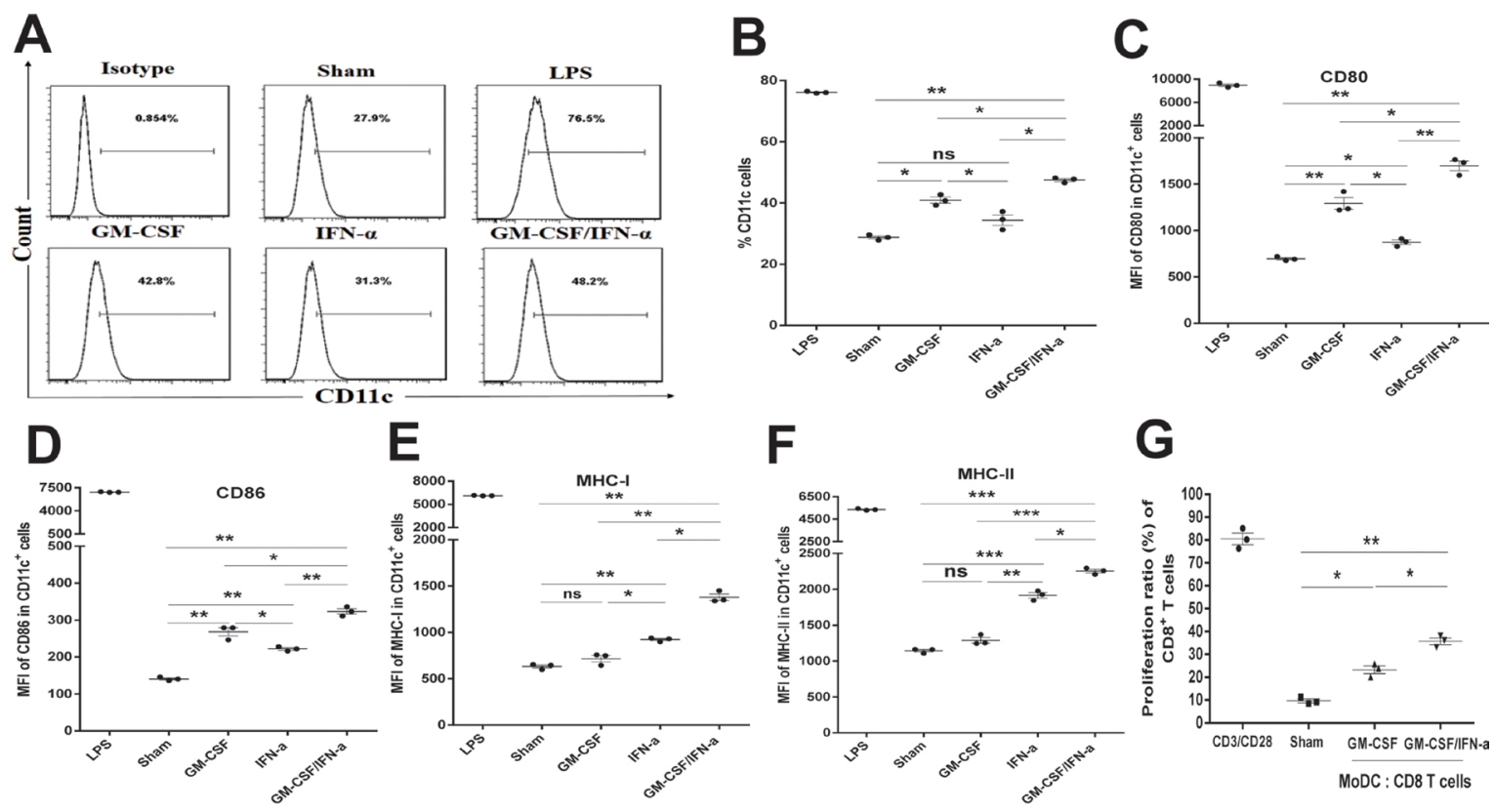

G
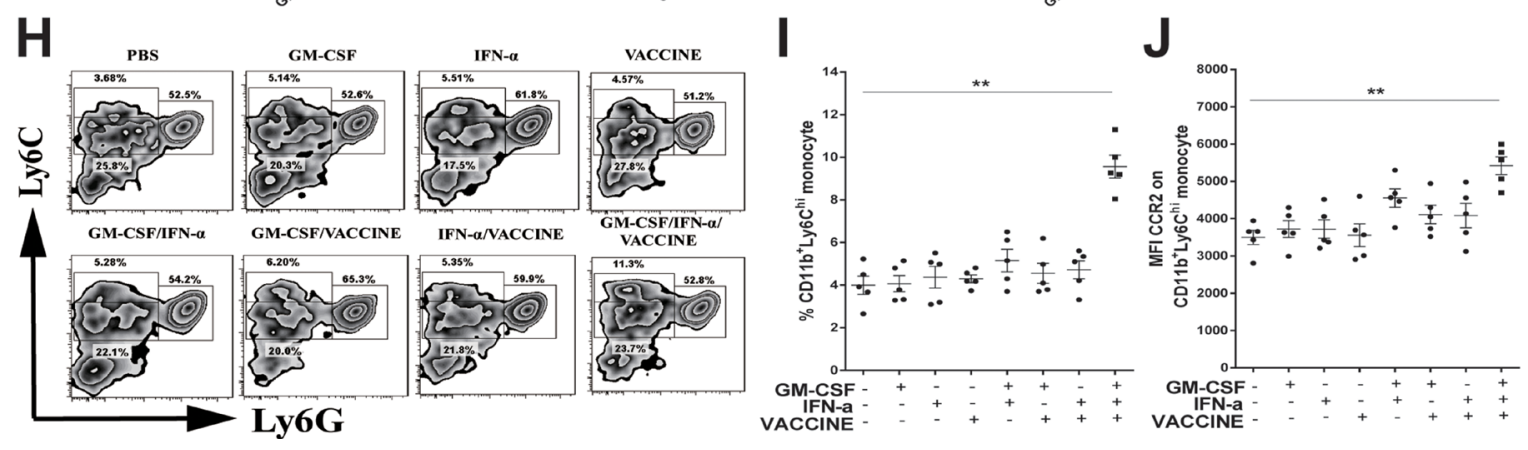

Figure 5: GM-CSF plus IFN- $\alpha$ promoted both the production and the function of CD11 ${ }^{+}$monocyte derived DC (MoDC) in vitro and in vivo. (A) $\mathrm{CD} 11 \mathrm{~b}^{+} \mathrm{Ly}_{6 \mathrm{G}}{ }^{-}$monocytes were sorted from $\mathrm{PBMC}$ of male wild-type $\mathrm{C} 57 \mathrm{BL} / 6$ mice $(n=50)$, then treated with $\mathrm{mGM}-\mathrm{CSF}(50 \mathrm{ng} / \mathrm{mL})$ and $\mathrm{mIFN}-\alpha(50 \mathrm{IU} / \mathrm{mL})$ once per day for 3 days before the frequencies of CD $11 \mathrm{c}^{+}$cells $(\mathrm{MoDC})$ were determined. LPS $(1 \mu \mathrm{g} / \mathrm{mL})$ was used as a positive control. (B) The percentage of CD11 $\mathrm{c}^{+}$DC induced by different cytokine formulations is shown. (C-F) Comparison of CD80, CD86, MHC-I, and MHC-II on the variously induced CD11 $\mathrm{c}^{+}$MoDC. (G) MoDC were further cultured for $72 \mathrm{~h}$ with splenic $\mathrm{CD} 8^{+} \mathrm{T}$ cells from AAV8-1.3HBV mice at a DC: T ratio of $1: 10$ and with $\mathrm{HBs} \mathrm{Ag}(10 \mu \mathrm{g} / \mathrm{mL})$ then proliferative responses were assessed. Cells incubated with anti-CD3 $(1 \mu \mathrm{g} / \mathrm{mL})$ and anti-CD28 $(100 \mathrm{ng} / \mathrm{mL})$ were used as positive controls. The GM-CSF/IFN- $\alpha-$ induced MoDC promoted a significantly higher level of CD8 ${ }^{+}$T-cell proliferation than was promoted by GM-CSF-induced MoDC. (H-J) $\mathrm{CD}_{11} \mathrm{~b}^{+}$Ly6 $\mathrm{C}^{\text {hi }}$ monocytes and $\mathrm{CD} 11 \mathrm{~b}^{+}$Ly6 $\mathrm{C}^{\text {lo }}$ monocytes in blood from AAV8-1.3HBV-infected mice that was collected $24 \mathrm{~h}$ after the second immunization with $3 \times \mathrm{GM}-\mathrm{CSF}+\mathrm{VACCINE}$ were quantified by flow cytometry and expressed as a percentage of total CD $11 \mathrm{~b}^{+}$cells $(\mathbf{H}, \mathbf{I})$. Numbers adjacent to outlined area indicate percent CD11 b ${ }^{+} \mathrm{Ly} 6 \mathrm{C}^{\text {hi }}$ monocytes (top left), CD11 b ${ }^{+}$Ly6 $\mathrm{C}^{\text {lo }}$ monocytes (bottom left), and $\mathrm{CD}_{11} \mathrm{~b}^{+}$Ly $6 \mathrm{G}^{+}$granulocytes (right). The CD11 $\mathrm{b}^{+}$Ly6C $\mathrm{C}^{\text {hi }}$ monocytes within the top left square were gated CCR2 $2^{+}$(J) Comparison of MFI of CCR2 on CD11 b ${ }^{+}$Ly $6 \mathrm{C}^{\text {hi }}$ monocytes of AAV8-1.3HBV-infected mice that had been immunized twice with different formulations of the vaccine. The cells were collected $24 \mathrm{~h}$ after the second immunization. Data are pooled from three independent experiments with 5 mice per group. Bars are shown as mean \pm SEM. ${ }^{*} P<0.05 ;{ }^{* *} P<0.01 ;{ }^{* * *} P<0.001$; ns, not significant. 
to GM-CSF and IL-4 [53]. Since Ronald et al. first reported that monocytes could differentiate into DC that had potent ability to elicit $\mathrm{T}$ cell immunity on exposure to GM-CSF and IFN- $\alpha$ [54], multiple reports have recognized the benefit of IFN- $\alpha$-MoDC vaccines $[55,56]$. IFN- $\alpha$ is crucial for the generation of Ly $6^{\text {hi }}$ monocytes [57] and can accelerate DC maturation, promote co-stimulation factor expression and pro-inflammatory cytokine secretion [29]. Since IFN $\alpha-M o D C$ has the capacity to cross-present antigen to $\mathrm{CD} 8^{+} \mathrm{T}$ cells, in contrast to IL-4-MoDC, there is growing interest in the use of IFN $\alpha$-MoDC to treat tumors and infectious diseases [58-61]. Whether the DC that are generated from GM-CSF plus IFN- $\alpha$ in the current recombinant HBV vaccine actually facilitate the

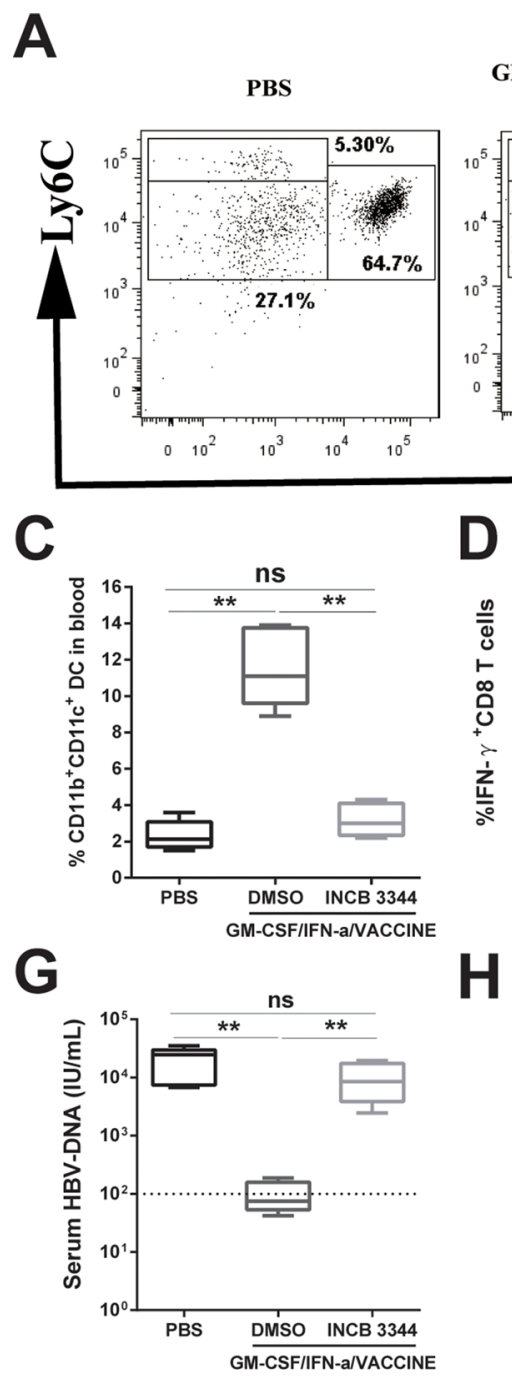

GM-CSF/IFN- $\alpha /$ VACCINE +DMSO
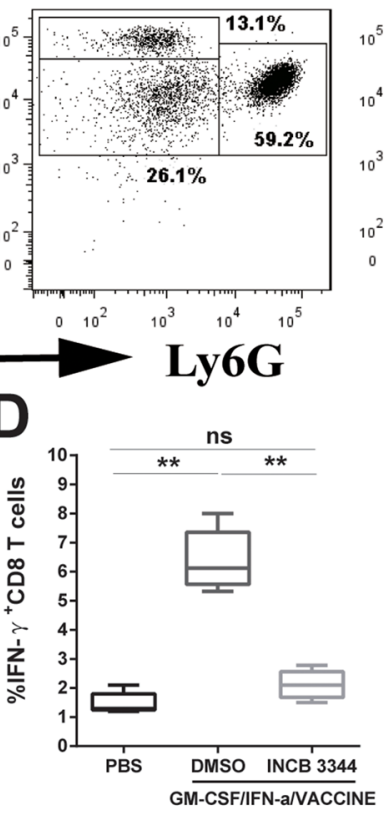

$H$ therapeutic treatment has not been established. This study is the first to demonstrate that the GM-CSF/IFN- $\alpha / \mathrm{HBV}$ vaccine regimen could overcome immune tolerance and promote robust anti-HBV-specific immune responses. However, an optimal dose combination of $\mathrm{HBV}$ vaccine with GM-CSF and IFN- $\alpha$ preferentially promoted monocyte polarization into DC rather than macrophages, in line with DC having a superior role in immune activation. Here, the presence of viral antigen in the formulation was critical for the monocyte differentiation, suggesting an antigen-specific response was induced amongst the heightened inflammatory response.

$\mathrm{HBV}$-specific $\mathrm{CD} 8^{+} \mathrm{T}$ cells are known to be the vital effectors contributing to the HBV clearance. Exhausted
GM-CSF/IFN- $\alpha /$ VACCINE + INCB3344
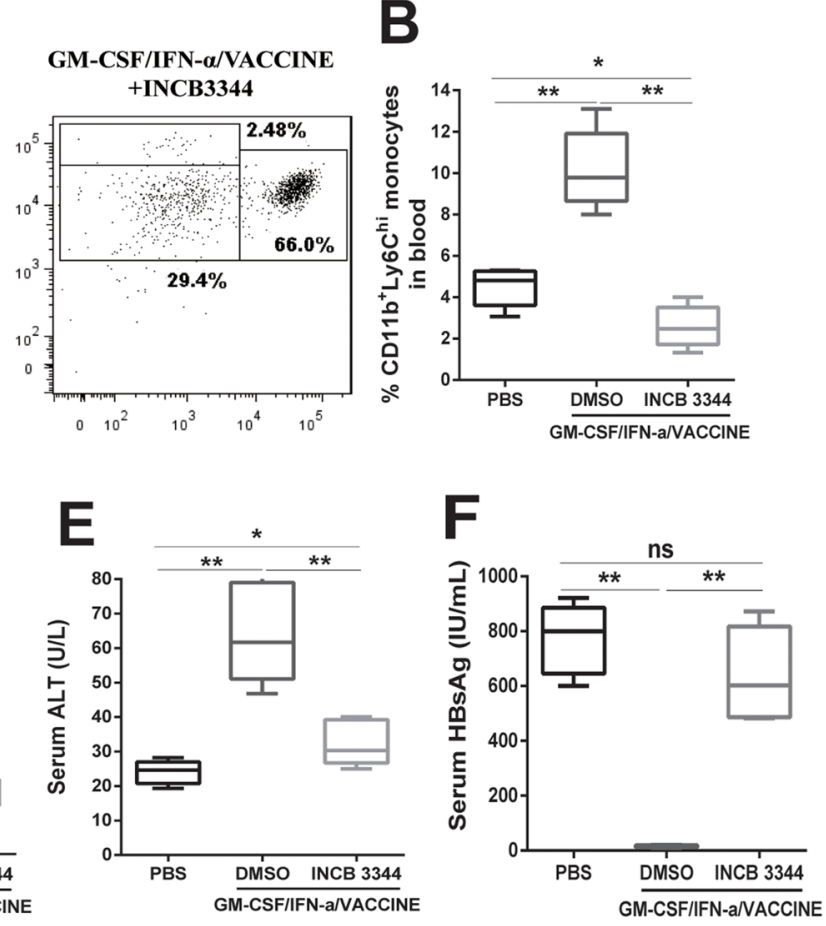

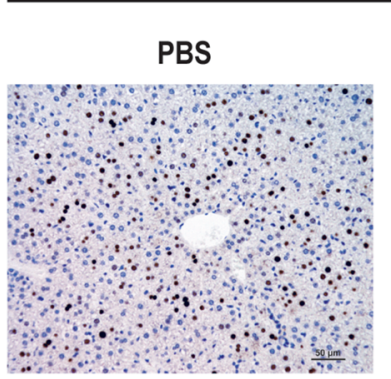

$\mathrm{HBcAg}$

GM-CSF/IFN- $\alpha /$ VACCINE + DMSO

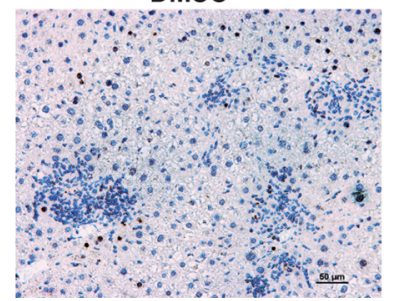

GM-CSF/IFN- $\alpha /$ VACCINE + INCB3344

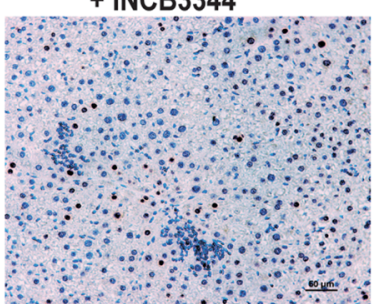

Figure 6: Blockage of $\mathrm{Ly}^{\mathrm{hi}}$ monocytes abrogates the $\mathrm{HBV}$ clearance caused by GM-CSF/IFN- $/ \mathrm{VACCINE}$ treatment. AAV8-1.3HBV infected mice were treated with CCR2 antagonist (INCB 3344, $30 \mathrm{mg} / \mathrm{kg}$ per day for 3 days) by intraperitoneal injection after the GM-CSF/IFN- $\alpha$ /VACCINE administration. The CD11b+Ly6C hi monocytes was measured $12 \mathrm{~h}$ after the third INCB 3344 administration. (A) Representative flow-cytometric images are shown ( $n=5-6$ mice per group). (B) CD11b ${ }^{+}$Ly6C ${ }^{\text {hi }}$ monocytes were quantified by percentage of total $\mathrm{CD} 11 \mathrm{~b}^{+}$cells. (C) $\mathrm{CD} 11 \mathrm{~b}^{+} \mathrm{CD} 11 \mathrm{c}^{+} \mathrm{DC}$ in blood were analyzed $12 \mathrm{~h}$ after the third INCB 3344 administration and quantified by percentage of total $\mathrm{CD} 11 \mathrm{~b}^{+}$cells. (D-G) IFN- $\gamma^{+} \mathrm{CD}^{+} \mathrm{T}$ cells in spleen, serum ALT, serum HBsAg, and serum HBV DNA were measured at 14 days after the fourth vaccination. The dotted line in $\mathrm{G}$ represents the assay limit of detection. Bars represent the mean \pm SEM. ${ }^{*} P<0.05 ;{ }^{* *} P<0.01$; ns, not significant. $(\mathbf{H}) 14$ days after the fourth vaccination, the HBcAg in liver sections was stained by IHC (brown). Representative images are shown ( $n=5$ mice per group). Scale bar represents $50 \mu \mathrm{m}$. 
$\mathrm{CD}^{+} \mathrm{T}$ cells expressing inhibitory receptors, including PD-1, CTLA-4, and TIM-3 are thought to underlie the major defect in HBV viral clearance [62]. However, clinical trials with the anti-PD-1 against CHB have had only limited success [63], suggesting that a reactivation of these exhausted $\mathrm{CD}^{+} \mathrm{T}$ cells may not be sufficient; the intrahepatic virus-specific CTLs from chronic patients have higher PD-1 expression [64] and are less susceptible to functional restoration by PD-1/PD-L1 blockade [65], as compared to circulating virus-specific CTLs. An ideal approach therefore may be to freshly active the naïve $\mathrm{CD}^{+} \mathrm{T}$ cell pool. In our current study, the GM-CSF/ IFN- $\alpha /$ VACCINE significantly promoted IFN- $\gamma$ secretion by $\mathrm{CD}^{+} \mathrm{T}$ cells and enhanced a powerful CTL response mediating the elimination of $\mathrm{HBcAg}$-positive hepatocytes. Although we demonstrated that the GM-CSF/IFN- $\alpha$ / VACCINE treatments could reduce the level of HBV DNA in serum, the liver HBV DNA was not completely cleared by the treatments. It appears that HBV-specific CTLs in the liver are insufficient to clear infected hepatocytes [66], suggesting that a subsequent treatment should be considered. Intrahepatic $\mathrm{HBV}$-specific $\mathrm{CD}^{+} \mathrm{T}$ cells have been shown to be key to the functional recovery of antiHBV immunity [67]. Consistent with this, we observed $\mathrm{CD}^{+} \mathrm{T}$ cell numbers increased in the livers in the GM-CSF/ IFN- $\alpha$ /VACCINE group, suggesting recruitment from the peripheral blood. Moreover, we observed that IL-12, a key cytokine inducing naïve $\mathrm{T}$ cells differentiation into effector $\mathrm{T}$ cells was higher in the GM-CSF/IFN- $\alpha$ /VACCINE group than in other groups. These results suggest that the recruited $\mathrm{CD}^{+} \mathrm{T}$ cells contributed to the HBV clearance following the GM-CSF/IFN- $\alpha$ /VACCINE treatment.

Serum HBsAg levels have been found to reflect the transcriptional activity of the cccDNA; measurement can help predict disease progression in patients [68, 69], and studies have indicated that the levels of serum $\mathrm{HBsAg}$ contribute to the liver fibrosis severity in $\mathrm{HBeAg}-$ positive patients $[70,71]$. In $\mathrm{HBeAg-negative} \mathrm{patients,}$ serum HBsAg level $<1000 \mathrm{IU} / \mathrm{mL}$ can be used to define patients at lower risk of HCC [72]. Furthermore, Chen and colleagues demonstrated that 9-year cumulative HCC incidences were $<1 \%$ after the patients had antiHBsAg and anti-HBeAg seroconversions [73]. In this study, $\mathrm{HBeAg}$ and $\mathrm{HBsAg}$ seroclearance occurred only in mice given the GM-CSF/IFN- $\alpha$ /VACCINE treatments. Notably, enhanced HBsAb productions were also observed by the GM-CSF/IFN- $\alpha$ /VACCINE treatments. Taking the evidence together, it may be that the progression of liver diseases could be delayed if $\mathrm{CHB}$ patients treated by the GM-CSF/IFN- $\alpha$ /VACCINE regimens.

Several limitations existed in this study. First, we observed that recombinant $\mathrm{AAV} / \mathrm{HBV}$ infection could last for more than 10 months in C57BL/6 mouse and the $\mathrm{AAV} / \mathrm{HBV}$-infected mice did not respond to the routine recombinant $\mathrm{HBs}$ vaccine. These results demonstrated that recombinant $\mathrm{AAV} / \mathrm{HBV}$ could chronically infect the mice and lead to immunotolerance in this mouse model. However, in the model the mice are infected with the recombinant $\mathrm{AAV} / \mathrm{HBV}$ for 3 weeks at the time of the first vaccination, while human patients are chronically infected with HBV for decades. Hence there is a significantly different character of immune tolerance and exhaustion in this model compared to human patients. Further rigorous study is warranted. Second, how the hepatic immune populations responded to the GM-CSF/IFN- $\alpha$ /VACCINE treatments was not fully defined and future investigation is needed.

\section{MATERIALS AND METHODS}

\section{Animals, virus and reagents}

C57BL/6 male mice (six- to eight-week-old) were obtained from Huafukang Laboratory Animal Co. Ltd (Beijing, China). All mice were housed in individual specific pathogen-free ventilated cages following the Institutional Animal Care guidelines of Fudan University. AAV8-1.3HBV virus which carries 1.3 copies of HBV genome (genotype D, serotype ayw) packaged in AAV serotype 8 vector was purchased from FivePlus Molecular Medicine Institute (Beijing, China). Alum-absorbed Chinese hamster ovary cells-derived recombinant HBsAg (VACCINE, hereafter) and recombinant human GMCSF were kindly gifted by the Jingtan Biotech Corp. of China North Pharmaceutical Group (Shijiazhang, China). Recombinant human Interferon- $\alpha$ (IFN- $\alpha$ ) was purchased from Kawin Technology, Ltd (Beijing, China). Mouse GM-CSF and mouse IFN- $\alpha$ was bought from Sino Biological Inc (Beijing, China). Purified recombinant HBsAg (rHBsAg) was obtained from Guikang Biotechnology, Ltd (Shanghai, China).

\section{Animal model}

Each mouse received $1 \times 10^{10}$ TCID50 of AAV8$1.3 \mathrm{HBV}$ virus through a tail vein injection according to the manufacturer's instruction. Serum collected from infected mice was used to monitor HBV DNA, HBsAg, HBsAb and $\mathrm{HBeAg}$ for 14 days post-infection.

\section{Immunization}

The AAV8-1.3HBV mice were randomly assigned to eight groups $(n=5)$ following the design shown in Table 1. GM-CSF $(10 \mu \mathrm{g})$, IFN- $\alpha$ (10,000 IU), and VACCINE $(1 \mu \mathrm{g})$ were injected subcutaneously following the immunization procedure on day 0 . Three subcutaneous boosts were administrated on days 14, 28, 49 .

\section{Generation of monocyte-derived DC (MoDC)}

CD11b ${ }^{+}$Ly6G- monocytes were sorted from PBMC of male wild-type C57BL/6 mice $(n=50)$ with Easysep ${ }^{\mathrm{TM}}$ 
Table 1: Immunization groups

\begin{tabular}{ll}
\hline Group & Dose \\
\hline (1)PBS & - \\
(2)GM-CSF & $10 \mu \mathrm{g}$ \\
(3)IFN- $\alpha$ & $10,000 \mathrm{IU}$ \\
(4)VACCINE & $1 \mu \mathrm{g}$ \\
(5) GM-CSF/IFN- $\alpha$ & $10 \mu \mathrm{g} / 10,000 \mathrm{IU}$ \\
(6) GM-CSF/VACCINE & $10 \mu \mathrm{g} / 1 \mu \mathrm{g}$ \\
(7)IFN- $\alpha$ /VACCINE & $10,000 \mathrm{IU} / 1 \mu \mathrm{g}$ \\
(8) GM-CSF/IFN- $\alpha /$ VACCINE & $10 \mu \mathrm{g} / 10,000 \mathrm{IU} / 1 \mu \mathrm{g}$ \\
\hline
\end{tabular}

Forty AAV8-1.3HBV infected mice were randomly divided into eight experimental and control groups, with five mice in each group. GM-CSF $(10 \mu \mathrm{g})$, IFN- $\alpha(10,000 \mathrm{IU})$, and VACCINE $(1 \mu \mathrm{g})$ were injected subcutaneously following the immunization design. PBS was used as sham control.

mouse monocyte isolation kit (STEMCELL, Canada). $\mathrm{CD} 11 \mathrm{~b}^{+} \mathrm{Ly} 6 \mathrm{G}^{-}$monocytes were incubated at $37^{\circ} \mathrm{C}$ in a humidified 5\% (v/v) $\mathrm{CO}_{2}$ air atmosphere in RPMI 1640 medium supplemented with $10 \%$ fetal bovine serum $(\mathrm{v} / \mathrm{v})$, penicillin $(100 \mathrm{U} / \mathrm{mL})$, and streptomycin $(100 \mu \mathrm{g} / \mathrm{mL})$. Monocytes were cultured in the medium with recombinant mouse GM-CSF (rmGM-CSF, $50 \mathrm{ng} / \mathrm{mL}$ ), recombinant mouse IFN- $\alpha(\mathrm{rmIFN}-\alpha, 25 \mathrm{ng} / \mathrm{mL}, 2,000 \mathrm{IU} / \mu \mathrm{g})$, and LPS $(1 \mu \mathrm{g} / \mathrm{mL})$ at $2 \times 10^{5} / \mathrm{mL}$ in 24 -well cell culture plates for 3 days. The cells in semi-suspension were identified as MoDC.

\section{In vitro MoDC and $\mathrm{T}$ cell co-culture}

Conventional $\mathrm{CD} 8^{+} \mathrm{T}$ cells were sorted (MajoSort, Biolegend) from splenocytes of AAV8-1.3HBV infected mice and labeled with carboxyfluorescein diacetate succinimidyl ester (CFSE). GM-CSF derived or GM-CSF/ IFN- $\alpha$ derived MoDC were incubated with HBsAg $(10 \mu \mathrm{g} /$ $\mathrm{mL}$ ) for $24 \mathrm{~h}$ before being mixed with the purified $\mathrm{CD} 8^{+}$ $\mathrm{T}$ cells $\left(2 \times 10^{5}\right.$ cells/well $)$ at a T:MoDC ratio of $10: 1$. After 3 -day co-culture, cells were analyzed by flow cytometry.

\section{Delayed-type hypersensitivity (DTH) assay}

On day 14 after the fourth vaccination, mice in each group were challenged with $10 \mu \mathrm{g}$ of rHBsAg in the left footpad as a test and phosphate buffered saline in the right footpad as a control. Swelling was measured after 24 and $48 \mathrm{~h}$ using a micrometer. Results are presented as mean \pm standard deviation in footpad thickness of left versus right footpad.

\section{In vitro $T$ cell proliferation assay}

On day 14 after the fourth immunization, all mice were sacrificed and single lymphocyte suspensions were prepared from spleens. A commercially available cellproliferation dye (CFSE) was used to assess lymphocyte proliferation. This fluorochrome-tagged dye binds to cellular proteins containing primary amines and is distributed equally to daughter cells upon division; thus, as cells divide, fluorescent staining becomes less bright. In vitro $\mathrm{T}$ cell proliferation was measured as reported previously [74]. Briefly, CFSE was added at a concentration of $1 \mu \mathrm{M}$ to washed splenocytes $\left(5 \times 10^{5}\right.$ cells). The cells were incubated for $10 \mathrm{~min}$ at $37^{\circ} \mathrm{C}$ in the dark, and labeling was stopped by adding RPMI 1640 supplemented with $10 \%$ fetal bovine serum (FBS). The cells were washed 3 times with medium and transferred to 96-well plates. Then the cells were incubated with HBsAg-specific CTL epitope $\mathrm{S}_{208-215}$ (ILSPFLPL; H-2 ${ }^{\text {b- }}$ restricted, $1 \mu \mathrm{g} / \mathrm{L}$ ) as a specific stimulator in the presence of anti-CD28 $(100 \mathrm{ng} / \mathrm{mL})$. Cells incubated with antiCD3 $(1 \mu \mathrm{g} / \mathrm{mL})$ and anti-CD28 $(100 \mathrm{ng} / \mathrm{mL})$ were used as positive controls. The plates were incubated at $37^{\circ} \mathrm{C}$ in a humidified atmosphere with $5 \% \mathrm{CO}_{2}$ for $72 \mathrm{~h}$ before the labeled cells were determined by flow cytometric analysis.

\section{Serological and biochemical analysis}

Serum HBsAg, $\mathrm{HBsAb}$ and $\mathrm{HBeAg}$ were determined by ELISA kits purchased from Kehua Bioengineering Co. Ltd (Shanghai, China). Serum IL-12, IL-4 and MCP-1 were tested by ELISA kits (eBioscience, USA). Serum alanine aminotransferase activity (ALT) was measured with ALT kit from BioSino Bio-technology and Science Inc. (Beijing, China).

\section{HBV DNA quantitation}

Serum HBV DNA was determined by real-time quantitative PCR with a kit from Kehua Bio-engineering Co., Ltd (Shanghai, China). The detection lower limit was at $100 \mathrm{IU} / \mathrm{mL}$.

\section{In vivo cytotoxic lysis assay}

OVA-specific CTL epitope OVA 257-264 (SIINFWKL) and HBsAg-specific CTL epitope $\mathrm{S}_{208-215}$ (ILSPFLPL; 
$\mathrm{H}-2^{\mathrm{b}}$-restricted) were synthesized by Sangon Biotech (Shanghai, China). In vivo cytotoxic lysis assay was conducted as described previously [28]. Briefly, to provide non-HBV target controls, splenocytes from naïve C57BL/6 donor mice were labeled with $15 \mu \mathrm{M}$ of CFSE and pulsed with $1 \mu \mathrm{g} / \mathrm{mL}$ of S208-215 (CFSE $^{\text {high }}$ target cells). An equal fraction of splenocytes were labeled with $1 \mu \mathrm{M}$ of CFSE and pulsed with $1 \mu \mathrm{g} / \mathrm{mL}$ of OVA257264 (CFSE $^{\text {low }}$ target cells). A mixture of $\mathrm{CFSE}^{\text {high }}$ and $\mathrm{CFSE}^{\text {low }}$ cells at a 1:1 ratio was adoptively transferred intravenously into immunized recipients at $2 \times 10^{7}$ cells per mouse on the 14th day after the fourth vaccination. Eight hours later, the splenocytes were isolated from the recipients and CFSE fluorescence intensities were analyzed by FACS.

\section{Blockage of CCR2 ${ }^{+}$monocytes with INCB 3344}

The AAV8-1.3HBV infected mice were randomly assigned to receive PBS, INCB 3344 (30 mg/kg per day for three days, $n=5$, MedChem Express, USA), or vehicle ( $10 \%$ dimethylsulfoxide, DMSO, $n=5)$ via intra-peritoneal injection at $1 \mathrm{~h}$ before the GMCSF/IFN- $\alpha$ /VACCINE inoculation. PBS, INCB 3344 or DMSO injection was repeated on days 2 and 3 . Ly $6 \mathrm{C}^{\text {hi }} \mathrm{CCR} 2^{+}$monocytes were tested by flow cytometry $24 \mathrm{~h}$ later.

\section{Histology and immunohistochemistry (IHC) analysis}

For histological investigations livers were fixed with $4 \%$ formalin overnight and processed for paraffin embedding. $10-\mu \mathrm{m}$ sections were stained with hematoxylin-eosin (H\&E) and examined by light microscopy to determine liver lesions.

$\mathrm{HBcAg-positive} \mathrm{liver} \mathrm{cells} \mathrm{and} \mathrm{infiltration}$ inflammatory cells were further examined by IHC analysis. For staining of $\mathrm{HBcAg}$ and $\mathrm{CD} 8,10-\mu \mathrm{m}$ sections of livers were fixed with ice-cold methanol for $30 \mathrm{~min}$, dehydrated through graded alcohols and subjected to antigen retrieval using $10 \mathrm{mM}$ sodium citrate. Sections were washed with tris borate saline Tween-20 (TBST) and then blocked with 2\% bovine serum albumin (BSA) for $1 \mathrm{~h}$. Liver sections were incubated with the respective mouse monoclonal antiHBcAg or anti-CD8. Slides were then washed for $5 \mathrm{~min}$ in TBST and incubated for $1 \mathrm{~h}$. After washing, section were incubated with goat anti-mouse horseradish peroxidase antibody for $1 \mathrm{~h}$. Finally, slides were incubated with 3,3-diaminobenzidine (DAB) chromogen solution and then counterstained with hematoxylin. Slides were then observed under a Nikon microscope and NIS elements microscope software (Nikon). Ten different fields were examined in each case.

\section{Flow cytometry}

Flow cytometry was performed on a FACS LSRFortessa flow cytometer with Diva software (BD Bioscience, USA). For DC analysis in vitro and in vivo, the cells were stained with CD11b (clone: M1/70, BioLegend), CD11c (clone: HL3, BD), CD80 (clone: 1610A1, eBioscience), CD86 (clone: GL-1, BioLegend), MHCI (clone: AF6.88.5.5.3, eBioscience), MHCII (clone: M5/114.15.2, eBioscience), PDCA-1 (clone: eBio927, eBioscience). For monocytes analysis in vivo, the cells were stained with CD11b (clone: M1/70, BioLegend), Ly6G (clone: RB6-8C5, eBioscience), Ly6C (clone: HK1.4, BioLegend), CCR2 (clone: SA203G11, BioLegend). For intracellular cytokine detection, the splenocytes were stimulated with $\mathrm{rHBsAg}(10 \mu \mathrm{g} / \mathrm{mL})$ for $18 \mathrm{~h}$. All samples included addition of $10 \mu \mathrm{g} / \mathrm{ml}$ Brefeldin A (BFA, BD) for the last $6 \mathrm{~h}$ of incubation. Tests included: PMA/ionomycin (100 ng/mL/1 $\mu \mathrm{g} /$ $\mathrm{mL}$ ) as positive control; Th1 (CD4 (clone: RM4-5, BioLegend); IFN- $\gamma$ (clone: XMG1.2, BioLegend); Th2 (CD4 (clone: RM4-5, BioLegend); anti-IL4 (clone: 11B11, BioLegend)); Tc1 (CD8 (clone: 53-6.7, eBioscience); anti-IFN- $\gamma$ (clone: XMG1.2, BioLegend)). Isotype-matched control $\mathrm{mAb}$ were used to identify nonspecific background staining.

\section{Statistics}

All results are presented as means \pm Standard Error of Mean (SEM). For continuous variables, Mann-Whitney $U$ test was used for abnormal distribution, the two-tailed Student's $t$-test for normal distribution and homogeneity of variance. A $P$ value of $<0.05$ was deemed significant for all analyses.

\section{Author contributions}

BW contributed to conceive the project, data evaluation and manuscript writing. WDZ designed and performed majority experiments, analyzed the data, and wrote the manuscript. GZ, SRZ, XZW and XPY helped with mice breeding, isolated cells and performed experiments.

\section{ACKNOWLEDGMENTS}

We thank Ms. Ying Wang of Jingtan Biotech Corp. for providing valuable human $\mathrm{HBV}$ vaccines and human recombinant GM-CSF. We appreciate Dr. Yan Shi for his valuable suggestions and careful proof reads. We are also grateful to Dr. Xianzheng Wang, Mr. Wencong Yu, Ms. Xiaoyu Zhou, Ms. Xian Zhou, Ms. Shijie Zhang and Ms. Yue He for their helpful discussions on this work. 


\section{CONFLICTS OF INTEREST}

The authors declare no financial or commercial conflicts of interest.

\section{FUNDING}

This work was supported by grants from the National Science and Technology Major Program of Infectious Diseases (2012ZX10002002004-001, 2012ZX10004701 and 2013ZX10002001) and Nature Science Foundation of China (31430027 and 81672016) to Dr. B. Wang.

\section{REFERENCES}

1. WHO. Guidelines for the prevention, care and treatment of persons with chronic hepatitis B infection. World Health Organization, Geneva. 2015.

2. Zhu RX, Seto WK, Lai CL, Yuen MF. Epidemiology of Hepatocellular Carcinoma in the Asia-Pacific Region. Gut Liver. 2016; 10:332-39.

3. Cho JY, Paik YH, Sohn W, Cho HC, Gwak GY, Choi MS, Lee JH, Koh KC, Paik SW, Yoo BC. Patients with chronic hepatitis $\mathrm{B}$ treated with oral antiviral therapy retain a higher risk for HCC compared with patients with inactive stage disease. Gut. 2014; 63:1943-50.

4. Buti M. HBeAg-positive chronic hepatitis B: why do i treat my patients with Nucleos(t)ide analogs? Liver Int. 2014; 34:108-11.

5. Fang Z, Li J, Yu X, Zhang D, Ren G, Shi B, Wang C, Kosinska AD, Wang S, Zhou X, Kozlowski M, Hu Y, Yuan Z. Polarization of Monocytic Myeloid-Derived Suppressor Cells by Hepatitis B Surface Antigen Is Mediated via ERK/IL-6/STAT3 Signaling Feedback and Restrains the Activation of T Cells in Chronic Hepatitis B Virus Infection. J Immunol. 2015; 195:4873-83.

6. Shrivastava S, TrehanPati N, Patra S, Kottilil S, Pande C, Trivedi SS, Sarin SK. Increased regulatory T cells and impaired functions of circulating CD8 T lymphocytes is associated with viral persistence in Hepatitis B viruspositive newborns. J Viral Hepat. 2013; 20:582-91.

7. Wang Q, Luan W, Warren L, Fiel MI, Blank S, Kadri H, Tuvin D, Hiotis SP. Serum hepatitis B surface antigen correlates with tissue covalently closed circular DNA in patients with hepatitis B-associated hepatocellular carcinoma. J Med Virol. 2016; 88:244-51.

8. Li YW, Yang FC, Lu HQ, Zhang JS. Hepatocellular carcinoma and hepatitis B surface protein. World J Gastroenterol. 2016; 22:1943-52.

9. Feld JJ, Wong DK, Heathcote EJ. Endpoints of therapy in chronic hepatitis B. Hepatology. 2009; 49:S96-102.

10. Liu J, Yang HI, Lee MH, Lu SN, Jen CL, BatrlaUtermann R, Wang LY, You SL, Hsiao CK, Chen PJ, Chen CJ; R.E.V.E.A.L.-HBV Study Group. Spontaneous seroclearance of hepatitis B seromarkers and subsequent risk of hepatocellular carcinoma. Gut. 2014; 63:1648-57.

11. Milich D, Liang TJ. Exploring the biological basis of hepatitis B e antigen in hepatitis B virus infection. Hepatology. 2003; 38:1075-86.

12. Tseng TC, Kao JH. Treating Immune-tolerant Hepatitis B. J Viral Hepat. 2015; 22:77-84.

13. Roy MJ, Wu MS, Barr LJ, Fuller JT, Tussey LG, Speller S, Culp J, Burkholder JK, Swain WF, Dixon RM, Widera G, Vessey R, King A, et al. Induction of antigen-specific CD8+ $\mathrm{T}$ cells, $\mathrm{T}$ helper cells, and protective levels of antibody in humans by particle-mediated administration of a hepatitis B virus DNA vaccine. Vaccine. 2000; 19:764-78.

14. Luo J, Li J, Chen RL, Nie L, Huang J, Liu ZW, Luo L, Yan XJ. Autologus dendritic cell vaccine for chronic hepatitis B carriers: a pilot, open label, clinical trial in human volunteers. Vaccine. 2010; 28:2497-504.

15. Shouval D, Roggendorf H, Roggendorf M. Enhanced immune response to hepatitis $\mathrm{B}$ vaccination through immunization with a Pre-S1/Pre-S2/S vaccine. Med Microbiol Immunol. 2015; 204:57-68.

16. Zuckerman JN. Protective efficacy, immunotherapeutic potential, and safety of hepatitis B vaccines. J Med Virol. 2006; 78:169-77.

17. Yalcin K, Danis R, Degertekin H, Alp MN, Tekes S, Budak $T$. The lack of effect of therapeutic vaccination with a preS2/S HBV vaccine in the immune tolerant phase of chronic HBV infection. J Clin Gastroenterol. 2003; 37:330-35.

18. Mancini-Bourgine M, Fontaine H, Scott-Algara D, Pol S, Bréchot C, Michel ML. Induction or expansion of T-cell responses by a hepatitis B DNA vaccine administered to chronic HBV carriers. Hepatology. 2004; 40:874-82.

19. Yoon SK, Seo YB, Im SJ, Bae SH, Song MJ, You CR, Jang JW, Yang SH, Suh YS, Song JS, Kim BM, Kim CY, Jeong SH, Sung YC. Safety and immunogenicity of therapeutic DNA vaccine with antiviral drug in chronic HBV patients and its immunogenicity in mice. Liver Int. 2015; 35:805-15.

20. Xu DZ, Wang XY, Shen XL, Gong GZ, Ren H, Guo LM, Sun AM, Xu M, Li LJ, Guo XH, Zhen Z, Wang HF, Gong HY, et al, and YIC Efficacy Trial Study Team. Results of a phase III clinical trial with an HBsAg-HBIG immunogenic complex therapeutic vaccine for chronic hepatitis B patients: experiences and findings. J Hepatol. 2013; 59:450-56.

21. Lok AS, Pan CQ, Han SH, Trinh HN, Fessel WJ, Rodell T, Massetto B, Lin L, Gaggar A, Subramanian GM, McHutchison JG, Ferrari C, Lee H, et al. Randomized phase II study of GS-4774 as a therapeutic vaccine in virally suppressed patients with chronic hepatitis B. J Hepatol. 2016; 65:509-16.

22. Bhattacharya $\mathrm{P}$, Budnick I, Singh M, Thiruppathi M, Alharshawi K, Elshabrawy H, Holterman MJ, Prabhakar BS. Dual Role of GM-CSF as a Pro-Inflammatory and a 
Regulatory Cytokine: Implications for Immune Therapy. J Interferon Cytokine Res. 2015; 35:585-99.

23. Ju H, Xing W, Yang J, Zheng Y, Jia X, Zhang B, Ren H. An effective cytokine adjuvant vaccine induces autologous T-cell response against colon cancer in an animal model. BMC Immunol. 2016; 17:31.

24. Yu TW, Chueh HY, Tsai CC, Lin CT, Qiu JT. Novel GMCSF-based vaccines: One small step in GM-CSF gene optimization, one giant leap for human vaccines. Hum Vaccin Immunother. 2016; 12:3020-3028.

25. Parmiani G, Castelli C, Pilla L, Santinami M, Colombo MP, Rivoltini L. Opposite immune functions of GM-CSF administered as vaccine adjuvant in cancer patients. Ann Oncol. 2007; 18:226-32.

26. Kohanbash G, McKaveney K, Sakaki M, Ueda R, Mintz AH, Amankulor N, Fujita M, Ohlfest JR, Okada H. GMCSF promotes the immunosuppressive activity of gliomainfiltrating myeloid cells through interleukin-4 receptor- $\alpha$. Cancer Res. 2013; 73:6413-23.

27. Pilla L, Patuzzo R, Rivoltini L, Maio M, Pennacchioli E, Lamaj E, Maurichi A, Massarut S, Marchianò A, Santantonio C, Tosi D, Arienti F, Cova A, et al. A phase II trial of vaccination with autologous, tumor-derived heatshock protein peptide complexes Gp96, in combination with GM-CSF and interferon-alpha in metastatic melanoma patients. Cancer Immunol Immunother. 2006; 55:958-68.

28. Wang X, Dong A, Xiao J, Zhou X, Mi H, Xu H, Zhang J, Wang B. Overcoming HBV immune tolerance to eliminate $\mathrm{HBsAg}$-positive hepatocytes via pre-administration of GMCSF as a novel adjuvant for a hepatitis B vaccine in HBV transgenic mice. Cell Mol Immunol. 2016; 13:850-61.

29. Radvanyi LG, Banerjee A, Weir M, Messner H. Low levels of interferon-alpha induce CD86 (B7.2) expression and accelerates dendritic cell maturation from human peripheral blood mononuclear cells. Scand J Immunol. 1999; 50:499-509.

30. Leplina OY, Tyrinova TV, Tikhonova MA, Ostanin AA, Chernykh ER. Interferon alpha induces generation of semimature dendritic cells with high pro-inflammatory and cytotoxic potential. Cytokine. 2015; 71:1-7.

31. Trepiakas R, Pedersen AE, Met O, Svane IM. Addition of interferon-alpha to a standard maturation cocktail induces CD38 up-regulation and increases dendritic cell function. Vaccine. 2009; 27:2213-19.

32. Santini SM, Lapenta C, Logozzi M, Parlato S, Spada M, Di Pucchio T, Belardelli F. Type I interferon as a powerful adjuvant for monocyte-derived dendritic cell development and activity in vitro and in Hu-PBL-SCID mice. J Exp Med. 2000; 191:1777-88.

33. Kirkwood JM, Lee S, Moschos SJ, Albertini MR, Michalak JC, Sander C, Whiteside T, Butterfield LH, Weiner L. Immunogenicity and antitumor effects of vaccination with peptide vaccine+/-granulocyte-monocyte colonystimulating factor and/or IFN-alpha $2 b$ in advanced metastatic melanoma: Eastern Cooperative Oncology Group Phase II Trial E1696. Clin Cancer Res. 2009; 15:1443-51.

34. Guptan RC, Thakur V, Kazim SN, Sarin SK. Efficacy of granulocyte-macrophage colony-stimulating factor or lamivudine combination with recombinant interferon in non-responders to interferon in hepatitis B virus-related chronic liver disease patients. J Gastroenterol Hepatol. 2002; 17:765-71.

35. Yang D, Liu L, Zhu D, Peng H, Su L, Fu YX, Zhang L. A mouse model for HBV immunotolerance and immunotherapy. Cell Mol Immunol. 2014; 11:71-78.

36. Dion S, Bourgine M, Godon O, Levillayer F, Michel ML. Adeno-associated virus-mediated gene transfer leads to persistent hepatitis $B$ virus replication in mice expressing HLA-A2 and HLA-DR1 molecules. J Virol. 2013; 87:5554-63.

37. Zhu D, Liu L, Yang D, Fu S, Bian Y, Sun Z, He J, Su L, Zhang L, Peng H, Fu YX. Clearing Persistent Extracellular Antigen of Hepatitis B Virus: An Immunomodulatory Strategy To Reverse Tolerance for an Effective Therapeutic Vaccination. J Immunol. 2016; 196:3079-87.

38. Sun H, Bi L, Zhou J, Zhou D, Liu Y, Jin G, Yan W. Modulation of the function of dendritic cells in adolescents with chronic HBV infection by IFN- $\lambda 1$. Int $J$ Clin Exp Pathol. 2015; 8:1743-51.

39. Tamoutounour S, Guilliams M, Montanana Sanchis F, Liu H, Terhorst D, Malosse C, Pollet E, Ardouin L, Luche H, Sanchez C, Dalod M, Malissen B, Henri S. Origins and functional specialization of macrophages and of conventional and monocyte-derived dendritic cells in mouse skin. Immunity. 2013; 39:925-38.

40. Cheong C, Matos I, Choi JH, Dandamudi DB, Shrestha E, Longhi MP, Jeffrey KL, Anthony RM, Kluger C, Nchinda G, Koh H, Rodriguez A, Idoyaga J, et al. Microbial stimulation fully differentiates monocytes to DC-SIGN/ CD209(+) dendritic cells for immune T cell areas. Cell. 2010; 143:416-29.

41. Neal LM, Knoll LJ. Toxoplasma gondii profilin promotes recruitment of Ly6Chi CCR2+ inflammatory monocytes that can confer resistance to bacterial infection. PLoS Pathog. 2014; 10:e1004203.

42. Serbina NV, Pamer EG. Monocyte emigration from bone marrow during bacterial infection requires signals mediated by chemokine receptor CCR2. Nat Immunol. 2006; 7:311-17.

43. Brodmerkel CM, Huber R, Covington M, Diamond S, Hall L, Collins R, Leffet L, Gallagher K, Feldman P, Collier P, Stow M, Gu X, Baribaud F, et al. Discovery and pharmacological characterization of a novel rodentactive CCR2 antagonist, INCB3344. J Immunol. 2005; 175:5370-78.

44. Chu HX, Kim HA, Lee S, Broughton BR, Drummond GR, Sobey CG. Evidence of CCR2-independent transmigration of Ly6C(hi) monocytes into the brain after permanent cerebral ischemia in mice. Brain Res. 2016; 1637:118-27. 
45. Chu HX, Broughton BR, Kim HA, Lee S, Drummond GR, Sobey CG. Evidence That Ly6C(hi) Monocytes are Protective in Acute Ischemic Stroke by Promoting M2 Macrophage Polarization. Stroke. 2015; 46:1929-37.

46. Inaba K, Inaba M, Romani N, Aya H, Deguchi M, Ikehara S, Muramatsu S, Steinman RM. Generation of large numbers of dendritic cells from mouse bone marrow cultures supplemented with granulocyte/macrophage colonystimulating factor. J Exp Med. 1992; 176:1693-702.

47. van Montfort T, Melchers M, Isik G, Menis S, Huang PS, Matthews K, Michael E, Berkhout B, Schief WR, Moore JP, Sanders RW. A chimeric HIV-1 envelope glycoprotein trimer with an embedded granulocyte-macrophage colonystimulating factor (GM-CSF) domain induces enhanced antibody and $\mathrm{T}$ cell responses. J Biol Chem. 2011; 286:22250-61.

48. Zhu YT, Zhao Z, Fu XY, Luo Y, Lei CY, Chen W, Li F, Pang SY, Chen SS, Tan WL. The granulocyte macrophage-colony stimulating factor surface modified MB49 bladder cancer stem cells vaccine against metastatic bladder cancer. Stem Cell Res. 2014; 13:111-22.

49. Spearman P, Kalams S, Elizaga M, Metch B, Chiu YL, Allen M, Weinhold KJ, Ferrari G, Parker SD, McElrath MJ, Frey SE, Fuchs JD, Keefer MC, et al, and NIAID HIV Vaccine Trials Network. Safety and immunogenicity of a CTL multiepitope peptide vaccine for HIV with or without GM-CSF in a phase I trial. Vaccine. 2009; 27:243-49.

50. Overton ET, Kang M, Peters MG, Umbleja T, AlstonSmith BL, Bastow B, Demarco-Shaw D, Koziel MJ, Mong-Kryspin L, Sprenger HL, Yu JY, Aberg JA. Immune response to hepatitis B vaccine in HIV-infected subjects using granulocyte-macrophage colony-stimulating factor (GM-CSF) as a vaccine adjuvant: ACTG study 5220. Vaccine. 2010; 28:5597-604.

51. Sun HH, Zhou DF, Zhou JY. The role of DCs in the immunopathogenesis of chronic HBV infection and the methods of inducing DCs maturation. J Med Virol. 2016; 88:13-20.

52. Tian H, Shi G, Yang G, Zhang J, Li Y, Du T, Wang J, Xu F, Cheng L, Zhang X, Dai L, Chen X, Zhang S, et al. Cellular immunotherapy using irradiated lung cancer cell vaccine co-expressing GM-CSF and IL-18 can induce significant antitumor effects. BMC Cancer. 2014; 14:48.

53. Hiasa M, Abe M, Nakano A, Oda A, Amou H, Kido S, Takeuchi K, Kagawa K, Yata K, Hashimoto T, Ozaki S, Asaoka $\mathrm{K}$, Tanaka E, et al. GM-CSF and IL-4 induce dendritic cell differentiation and disrupt osteoclastogenesis through M-CSF receptor shedding by up-regulation of TNF-alpha converting enzyme (TACE). Blood. 2009; 114:4517-26.

54. Paquette RL, Hsu NC, Kiertscher SM, Park AN, Tran L, Roth MD, Glaspy JA. Interferon-alpha and granulocytemacrophage colony-stimulating factor differentiate peripheral blood monocytes into potent antigen-presenting cells. J Leukoc Biol. 1998; 64:358-67.
55. Lapenta C, Santini SM, Spada M, Donati S, Urbani F, Accapezzato D, Franceschini D, Andreotti M, Barnaba V, Belardelli F. IFN-alpha-conditioned dendritic cells are highly efficient in inducing cross-priming CD8(+) T cells against exogenous viral antigens. Eur J Immunol. 2006; 36:2046-60.

56. Lapenta C, Donati S, Spadaro F, Castaldo P, Belardelli F, Cox MC, Santini SM. NK Cell Activation in the Antitumor Response Induced by IFN- $\alpha$ Dendritic Cells Loaded with Apoptotic Cells from Follicular Lymphoma Patients. J Immunol. 2016; 197:795-806.

57. Seo SU, Kwon HJ, Ko HJ, Byun YH, Seong BL, Uematsu $\mathrm{S}$, Akira S, Kweon MN. Type I interferon signaling regulates Ly6C(hi) monocytes and neutrophils during acute viral pneumonia in mice. PLoS Pathog. 2011; 7:e1001304.

58. Pontillo A, Santillo BT, Duarte AJ, Oshiro TM. Differential inflammasome expression and IL- $1 \beta$ secretion in monocytederived dendritic cells differentiated with IL-4 or IFN- $\alpha$. AIDS Res Ther. 2013; 10:35.

59. Weng K, Xie X, Qiu G, Gu W. Clinical reagents of GM$\mathrm{CSF}$ and IFN- $\alpha$ induce the generation of functional chronic myeloid leukemia dendritic cells in vitro. Cytotechnology. 2012; 64:75-81.

60. Ruben JM, Bontkes HJ, Westers TM, Hooijberg E, Ossenkoppele GJ, de Gruijl TD, van de Loosdrecht AA. Differential capacity of human interleukin-4 and interferon- $\alpha$ monocyte-derived dendritic cells for crosspresentation of free versus cell-associated antigen. Cancer Immunol Immunother. 2015; 64:1419-27.

61. Spadaro F, Lapenta C, Donati S, Abalsamo L, Barnaba V, Belardelli F, Santini SM, Ferrantini M. IFN- $\alpha$ enhances cross-presentation in human dendritic cells by modulating antigen survival, endocytic routing, and processing. Blood. 2012; 119:1407-17.

62. Ye B, Liu X, Li X, Kong H, Tian L, Chen Y. T-cell exhaustion in chronic hepatitis B infection: current knowledge and clinical significance. Cell Death Dis. 2015; 6:e1694.

63. Bengsch B, Martin B, Thimme R. Restoration of HBVspecific CD8+ T cell function by PD-1 blockade in inactive carrier patients is linked to T cell differentiation. J Hepatol. 2014; 61:1212-19.

64. Golden-Mason L, Palmer B, Klarquist J, Mengshol JA, Castelblanco N, Rosen HR. Upregulation of PD-1 expression on circulating and intrahepatic hepatitis $\mathrm{C}$ virusspecific CD8+ T cells associated with reversible immune dysfunction. J Virol. 2007; 81:9249-58.

65. Nakamoto N, Cho H, Shaked A, Olthoff K, Valiga ME, Kaminski M, Gostick E, Price DA, Freeman GJ, Wherry EJ, Chang KM. Synergistic reversal of intrahepatic HCVspecific CD8 T cell exhaustion by combined PD-1/CTLA-4 blockade. PLoS Pathog. 2009; 5:e1000313.

66. Guidotti LG, Chisari FV. Noncytolytic control of viral infections by the innate and adaptive immune response. Annu Rev Immunol. 2001; 19:65-91. 
67. Fisicaro P, Valdatta C, Massari M, Loggi E, Biasini E, Sacchelli L, Cavallo MC, Silini EM, Andreone P, Missale G, Ferrari C. Antiviral intrahepatic T-cell responses can be restored by blocking programmed death-1 pathway in chronic hepatitis B. Gastroenterology. 2010; 138:682-693, 693.e1-4.

68. Chan HL, Thompson A, Martinot-Peignoux M, Piratvisuth T, Cornberg M, Brunetto MR, Tillmann HL, Kao JH, Jia JD, Wedemeyer H, Locarnini S, Janssen HL, Marcellin P. Hepatitis B surface antigen quantification: why and how to use it in 2011 - a core group report. J Hepatol. 2011; 55:1121-31.

69. Höner Zu Siederdissen C, Cornberg M. The role of HBsAg levels in the current management of chronic HBV infection. Ann Gastroenterol. 2014; 27:105-12.

70. Martinot-Peignoux M, Carvalho-Filho R, Lapalus $M$, Netto-Cardoso AC, Lada O, Batrla R, Krause F, Asselah T, Marcellin P. Hepatitis B surface antigen serum level is associated with fibrosis severity in treatment-naïve, e antigen-positive patients. J Hepatol. 2013; 58:1089-95.

71. Hong MZ, Huang WQ, Min F, Xu JC, Lin Z, Fang KN, Pan JS. Enhanced HBsAg synthesis correlates with increased severity of fibrosis in chronic hepatitis B patients. PLoS One. 2014; 9:e87344.

72. Fung J, Lai CL, Yuen MF. Hepatitis B virus DNA and hepatitis B surface antigen levels in chronic hepatitis B. Expert Rev Anti Infect Ther. 2010; 8:717-26.

73. Chen CJ, Yang HI, Su J, Jen CL, You SL, Lu SN, Huang GT, Iloeje UH, and REVEAL-HBV Study Group. Risk of hepatocellular carcinoma across a biological gradient of serum hepatitis B virus DNA level. JAMA. 2006; 295:65-73.

74. Quah BJ, Parish CR. The use of carboxyfluorescein diacetate succinimidyl ester (CFSE) to monitor lymphocyte proliferation. J Vis Exp. 2010. 